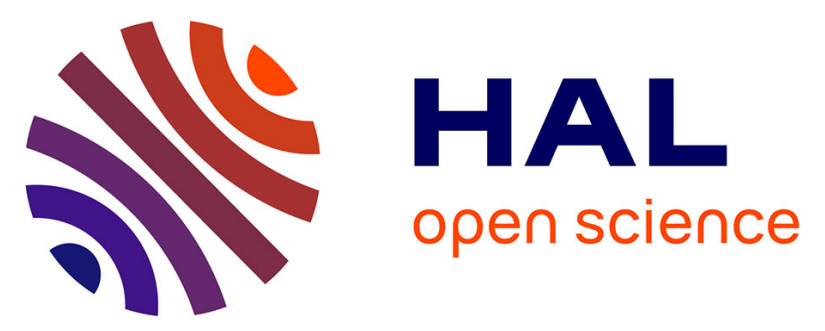

\title{
A late-Ordovician phreatomagmatic complex in marine soft-substrate environment: The Crozon volcanic system, Armorican Massif (France)
} Martial Caroff, Muriel Vidal, Antoine Bénard, Jean-René Darboux

\section{- To cite this version:}

Martial Caroff, Muriel Vidal, Antoine Bénard, Jean-René Darboux. A late-Ordovician phreatomagmatic complex in marine soft-substrate environment: The Crozon volcanic system, Armorican Massif (France). Journal of Volcanology and Geothermal Research, 2009, 184 (3-4), pp.351-366. 10.1016/j.jvolgeores.2009.05.002 . insu-00445509

\section{HAL Id: insu-00445509 \\ https://hal-insu.archives-ouvertes.fr/insu-00445509}

Submitted on 8 Jan 2010

HAL is a multi-disciplinary open access archive for the deposit and dissemination of scientific research documents, whether they are published or not. The documents may come from teaching and research institutions in France or abroad, or from public or private research centers.
L'archive ouverte pluridisciplinaire HAL, est destinée au dépôt et à la diffusion de documents scientifiques de niveau recherche, publiés ou non, émanant des établissements d'enseignement et de recherche français ou étrangers, des laboratoires publics ou privés. 


\section{A late-Ordovician phreatomagmatic complex in marine soft- substrate environment: the Crozon volcanic system,} Armorican Massif (France)

Martial Caroff*, Muriel Vidal, Antoine Bénard, Jean-René Darboux

Université Européenne de Bretagne, Université de Brest, CNRS IUEM, UMR nº538 « Domaines Océaniques » et Département des Sciences de la Terre, 6 avenue Victor Le Gorgeu, CS 93837, F-29238 Brest cedex 3, France

\footnotetext{
* Corresponding author: caroff@univ-brest.fr
} 


\section{Abstract}

The mafic lavas and the diabases of Crozon (Armorican Massif, France), belong to an anorogenic Ordovician volcanic complex, emplaced on a rifted passive margin in North Gondwana. Magma passed through syn-volcanic soft sedimentary substrate, which is today mostly composed of alternating sandstones and mudstones, from Llanvirn to Ashgill in age. Field observations together with microscopic studies and geochemical analyses of magmatic rocks lead us to propose a model of volcano formation which combines hydromagmatic processes, peperitic intrusions, a shallow submarine tephra settling, eruption-fed turbidity currents, and a pillow lava effusion. The Crozon outcrops can be used to reconstruct a complete cross-section from the root of the volcanic complex to the lavas and breccias emplaced on the sea floor. The sites expose: (i) an hypabyssal breccia containing mud chunks and coarse-grained diabase clasts with amoeboidal fine-grained magmatic material; (ii) bulbous peperitic sills and pillow-like lobes bearing a great quantity of sediment-derived enclaves of fluidal morphology; (iii) volcaniclastic breccias containing near-spherical magmatic clasts that resulted from the complete fragmentation of sills in the ductile regime; (iv) a rhythmic peperitic breccia interpreted as the product of mingling between thin lava flows and soft calcareous sediment. The Crozon volcanic form, resulting from explosive interaction with subsurface/surface water, was probably a subaqueous collapsed tuff cone. This upper part of the system is synchronous with an Ashgill carbonate sedimentation, which overlies an Ordovician siliciclastic succession deposited in shelf environments.

\section{Introduction}

Processes and products of magma-sediment mingling (peperite) and maar-diatreme volcanism have been the subjects of two Special Volumes of Journal of Volcanology and 
Geothermal Research, respectively Skilling et al. (2002a) and Martin et al. (2007). This illustrates the recent renewal of most of the concepts associated with both themes. The application of fuel-coolant interaction (FCI) theory is appropriate for interpretation of both peperite and maar/diatreme structures (Wohletz, 2002). Magma/wet sediment interactions involve heat transfer over a wide range of rates from mingling to explosive fragmentation. Fluidal peperite results from the development of a vapor film layer at the magma/sediment interface, acting as an insulating barrier. Explosive fragmentation occurs when the vapor film becomes unstable. The behavior of the vapor film is mainly controlled by the sediment characteristics, the hydrology, and the mass interaction ratio of wet sediment and magma. Wohletz (2002) suggested that the higher the ratio then the more unstable will be the vapor films around the hot magmatic clasts. According to Skilling et al. (2002b) and Templeton and Hanson (2003), fluidization is more efficient and vapor films are more stable when magma interacts with fine-grained, well-sorted, and loosely packed sediment. Some peperites are inferred to record frozen FCI coarse mixing-stage and thus, the mixing geometry recorded might be related to the processes governing the pre-explosive coarse mingling phase of FCI explosions (Hooten and Ort, 2002).

Inverted-cone-shaped diatremes are substructures typical of subaerial phreatomagmatic centers. They are filled with clastic debris derived from the surrounding rocks, juvenile clasts and subsided blocks, and they are typically cut by intrusive magmatic bodies (Martin et al., 2007). The volcanic forms classically associated with diatremes in subaerial environments are maars (tuff rings). Following White (1996), below sea level eruptions mainly result in either tuff cones (vigorous magmatic injection, persistent interaction of magma with sediment-laden coolant and explosivity) or pillow lavas (weak magmatic effusion, persistent interaction of magma with pure-water coolant and no 
explosivity). Although not excluded, diatreme formation in subaqueous environment has never been clearly established.

Within the early Palaeozoic sedimentary succession of the North Gondwana margin, the Upper Ordovician of the Medio-North-Armorican Domain (Western France) has been affected by an anorogenic volcanism, which is particularly well exposed in the Crozon Peninsula (Fig. 1). The four main interesting aspects of the Ordovician hypabyssal/volcanic exposures of Crozon consist in (i) the existence of several outcrops displaying features characteristic of the ancient volcanic substructure, such as normal faults, hydrothermalism, hypabyssal breccias and intrusions, (ii) the occurrence of a very well developed set of fluidal peperites, (iii) the presence of unusually abundant sediment-derived enclaves and clasts within sills and breccias, respectively, and (iv) the existence of calcareous levels, located at key positions in the volcanic succession, which offer valuable pieces of information on the deposit environment and depth.

\section{Geological context and lithostratigraphy}

The Crozon Peninsula displays a remarkable Palaeozoic sedimentary succession, from Brioverian (Upper Precambrian - Lower Palaeozoic) to upper Devonian. It is made up of two structural domains, the North Crozon domain locally overthrusting the South Crozon one (Darboux et Rolet, 1979; Rolet et al. 1984; Fig. 1a). Both domains were clearly part of the same palaeogeographic area and recorded the same palaeontological and sedimentary events (Robardet et al., 1994; Paris et al., 1999), except at the base and the top of the sedimentary piles where differences exist. The northern zone was probably located less than $30 \mathrm{~km}$ from the southern one during Ordovician, as shown by an (unpublished) palaeotectonic reconstruction. In the South Crozon area, the unconformable Palaeozoic succession starts with 
conglomerates and red siltstones, underlying the Armorican Sandstones (Fig. 2), whereas in the North, this latter formation rests directly on Brioverian. In both domains, Armorican Sandstones are overlain successively by Postolonnec (mudstones) and Kermeur (mainly sandstones) Formations (Llanvirn to Caradoc ages, sensu Fortey et al., 1995). Volcanics and limestones of the Rosan Formation (Ashgill) outcrop in the South domain only, overlain by Hirnantian sandstones (Plusquellec et al., 1999; Fig. 2). In the North area, sandstones and mudstones of the Kermeur Formation are directly overlain by Hirnantian glacio-marine deposits (Bourahrouh, 2002). From Middle (Llanvirn) to Upper (Ashgill) Ordovician, the South Crozon sedimentary succession contains many hypabyssal and volcanic rocks (Fig. 2): breccias and sills in the Postolonnec Formation (Llanvirn), sills and dykes in the Kermeur one (Caradoc), and breccias, sills, and pillow lavas in the Rosan Formation (Ashgill).

The present study focuses mainly on four sites located on Fig. 1b: i) Kerdreux, where sills and an hypabyssal breccia crop out within the mudstones of the Postolonnec Formation; ii) Postolonnec, where sills and normal fault-related hydrothermal breccias can be observed in mudstones; iii) Aber (Rosan Formation), which is a locality displaying the greatest range of volcanic breccias; iv) Lostmarc'h Headland (Rosan Formation), for pillow lavas and a rhythmic peperitic breccia. Additional dykes and sills from Kerdra (Kermeur Formation), Morgat and Trégarvan (Rosan Formation) have also been analysed for major and trace elements.

The studied area was deformed during the Variscan orogeny, leading to folds and cleavage development under anchizonal metamorphic conditions (Paradis et al., 1983). Structural analysis of coastal regions as well as regional mapping also give evidence for some major strike-slip and reverse faulting (Rolet et al., 1986; Fig. 1b). The magmatic sills and the volcanic successions are either steeply dipping (Kerdreux, Postolonnec, and Aber sites) or vertical (Lostmarc'h Headland). 
The sedimentary succession enclosing the hypabyssal and volcanic products represents unquestionably true marine accumulated deposits, as shown by the presence of fossils of stenohaline marine fauna as chitinozoans, trilobites, and echinoderms (Paris et al., 1999). Sedimentary structures such as shell beds, hummocky cross stratifications, and ripples attest that the entire Ordovician succession were deposited in shelf environments dominated by storm wave action (Paris et al., 1999; Dabard et al., 2007). Within or in the vicinity of the volcanic succession of Rosan, there are three calcareous bioclastic levels that have been carefully examined. At the top of the Kermeur succession of the Aber site, there is a condensed level formed by an oolithic iron bed overlain by a calcareous shell bed, with mostly brachiopods and bryozoa (L1 in Fig. 3). A few limestone beds containing a great amount of large disarticulated shells of brachiopods lie between the volcaniclastic deposits and the pillow lavas of the Aber site in the Rosan Formation (L2 in Fig. 3). Hummocky cross stratifications have been identified in this part of the section (A. Loi, pers. comm., 2009). Finally, volcanics are sealed at the Lostmarc'h site by a thick bioclastic limestone bed (L3 in Fig. 3), named the Porzhig limestone by Paris et al. (1999), which has yielded conodonts of Ashgill age (Paris et al., 1981), bryozoa and crinoids. Taking account of the stratigraphic correlations proposed by these authors, the succession comprised between the layers L1 and L3, which brackets all the Crozon subaqueous volcanic activity, corresponds to less than four millions years in duration (from the chronostratigraphic chart proposed by Webby et al., 2004).

The majority of the magmatic rocks from Crozon have been slightly hydrothermalized or weathered. We present in Table 1 five geochemical analyses (major and selected trace elements) of moderately/weakly altered sills, those with L.O.I. $<4 \mathrm{wt} \%$. Most of the intrusions, lavas and volcanic clasts from Crozon are mafic. The only intermediate compositions that have been analyzed are the Kerdra sill, which is trachybasaltic in 
composition. A large amount of the clasts occurring in the volcaniclastic deposits from Aber are vesicular, colourless, and have high silica contents $\left(\mathrm{SiO}_{2}>60 \mathrm{wt} \%\right)$, suggesting that they might be rhyolitic pumices. However, their high $\mathrm{Ni}$ and $\mathrm{Cr}$ values $(75<\mathrm{Ni}<121 \mathrm{ppm} ; 182<$ $\mathrm{Cr}<275 \mathrm{ppm}$ ) are not consistent with such a hypothesis (Juteau et al., 2007). These latter authors have interpreted the corresponding clasts as silicified basaltic fragments. All the magmatic products from Crozon have anorogenic affinities. They plot either in the withinplate field or in the ocean-floor one in the Pearce and Cann (1973) diagram (not shown). Trace element data can be used to identify alkalic and tholeiitic rocks, the first group being enriched in Light REE with respect to tholeiites (Table 1). The Trégarvan sample Ga1 has REE contents characteristic of a transitional magmatism. The geographic repartition of the alkalic versus tholeiitic rocks seems to be random.

\section{Hypabyssal facies}

The hypabyssal facies from Crozon include a breccia and intrusions. The hypabyssal breccia is only observable in a narrow Kerdreux outcrop while the intrusions, commonly sills, occur in every site.

\subsection{Hypabyssal breccia}

At the Kerdreux site, the lower part of the Postolonnec Formation (Fig. 2) is cut by several basaltic intrusions (Fig. 1b). Between a large coarse-grained sill and the Postolonnec mudstones, there is a complex brecciated zone, ca. $10 \mathrm{~m}$ in extent, including a range of angular or rounded polylithologic clasts of various sizes (from millimeter to decametre). The present dipping of the sharp breccia/diabase contact (ca. $70^{\circ} \mathrm{SE}$ ) suggests it was gently 
sloping when the volcanic system was active. The breccia/mudstone contact is not visible. Recognized as Facies A in Table 2 and Fig. 4a, this polymict breccia is chaotic (Fig. 2). It includes angular coarse-grained magmatic fragments, mm-to-dm in size, having a texture close to that of the adjacent sill. These components probably result from the fragmentation of the diabase. The second group of components is constituted by quartz-rich argillaceous clasts. They are present in great quantity everywhere in the breccia, sometimes prevailing. The largest ones are angular, but most of them, less than five centimeters long, are typically rounded and elongated. The smallest clasts display a fluidal morphology, with lobate margins (Fig. 5a), and can be interpreted as ancient mud chunks (in the sense of White, 1991 and Németh and Martin, 2007). A very few argillaceous clasts contain andalusite (Fig. 6a). The third component of the breccia consists of crystallite-bearing cryptocrystalline/fine-grained magmatic fluidal clasts, basaltic in composition. Their microtexture is similar to that of adjacent small lobate igneous bodies, a few meters in extent. These fluidal magmatic components are contemporaneous with the breccia formation. A few fine-grained magmatic fluidal clasts have a core formed by a coarse-grained magmatic fragment or a sedimentary argillaceous one (Fig. 5b). Matrix of the Kerdreux breccia is an intimated mix of the three macroscopic components, i.e. it is formed by crushed coarse-grained diabase mixed with fluidal argillaceous bits and amoeboidal fine-grained magmatic material.

\subsection{Diabases}

Dykes and especially sills can be observed in many places (Fig. 1b) intruding through various lithologic formations (Fig. 2). They intruded both the basement of the ancient volcano(es) (Postolonnec and Kermeur Formations) and the volcaniclastic deposits themselves (Rosan Formation). The largest intrusions form the Kerdreux and Kerdra 
headlands, in the Postolonnec and Kermeur Formations, respectively (Fig. 1b). The first one is bordered with the A-type breccia (see earlier in the text). Both are coarse-grained sills, from $100 \mathrm{~m}$ to $200 \mathrm{~m}$ in thickness, intruded by dykes and cut by hercynian E-W-trending strike-slip faults. Fracturing is especially severe near the contact with the A-type breccia.

In the Postolonnec cliffs, there are a number of sills of smaller thickness, intruded into the Postolonnec Formation. Their margins tend to have a fluidal geometry on any scale (Fig. 2). Cracks perpendicular to their margins are sometimes invaded by sediment (Fig. 5c). Some isolated amoeboid basaltic bodies, including fluidal sedimentary enclaves, can also be observed (Fig. 5d). Some fractures, cutting the cliffs, are filled-up either with crushed diabase or with quartz-bearing hydrothermal breccia, enclosing sedimentary and igneous pieces. The fractures are clearly pre-folding normal faults, which predate the Hercynian tectonic events. They were used as conduits by magmatic intrusions.

At the Aber site, we observe the passage from the Kermeur to the Rosan Formations. Both are intruded by fluidal sills (Fig. 2). An example of fluidal sill intruded into the Rosan volcaniclastic succession is shown as a photomontage in Fig. 7. Some of the sills change into pillow-like lobes at their tips (Fig. 7 inset). Pipe vesicles are sometimes visible close to both margins of the sills in the Kermeur Formation (Fig 5e). Vesicle veins have been observed above the pipe vesicles only at the basal margin of one sill (Fig. 5e). All the sills contain lots of fluidal sediment-derived chloritic enclaves, generally less than two centimeters in length (Fig. 5f).

\section{Volcanic breccias and pillow-lavas}

The volcanic breccias from Crozon are diversified. They can be divided into two groups according to the presence or not of peperitic features. The non peperitic group can be 
observed only at the Aber site whereas the peperitic one occurs both at the Aber area, above the non peperitic breccia succession, and at the Lostmarc'h site, just over pillow lavas (Fig. 3). All the breccia lithofacies are presented in Table 2, where are listed their codes, descriptions, interpretations, and reference figures or photos.

\subsection{Non peperitic volcanic breccias}

\subsubsection{Stratified polymict volcaniclastic deposits (BCD lithofacies association)}

This lithofacies association is exposed at the Aber site and comprises Facies B, C, and D (Fig. 3). Facies B, occurring just above the limestone bed L1, forms the base of the succession and facies $\mathrm{C}$ is interbedded with facies D (Fig. 3). Facies B consists of block-rich massive units, less than $2 \mathrm{~m}$ thick. In thin section, the rocks of facies B contain abundant fluidal and vesicular sediment-derived chloritic clasts together with a few angular, plagioclase-phyric and slightly vesicular volcanic fragments in a fine calcareous bioclastic matrix (Fig. 4b). Facies C breccia corresponds to thick (1-2 m), internally massive or weakly normally graded, poorly sorted beds (Fig. 4c). It contains predominantly fluidal sedimentderived chloritic clasts together with minor angular, vesicular to scoriaceous volcanic clasts in a siliceous matrix. We note also the occurrence of sparse armored lapilli, formed by lapillisized (more rarely block-sized) volcanic rock fragments concentrically coated by ancient bioclastic mud mixed with ash-sized glass shards and sediment-derived chloritic clasts (Fig. 8a). The matrix of the C-type breccia might correspond to an ancient limestone, secondarily silicified, as suggested by some textural similarities between facies B and C (comparable clasts/matrix proportions; similar bioclastic fragments of identical size in both matrix). Facies C resembles (1) the lapilli breccia described by McPhie (1995) in a Pliocene shoaling basaltic seamount from Fiji (stratified; thick; internally massive; moderately sorted; clast-supported; 
but matrix very minor with respect to the Crozon facies C); (2) the facies A of Rinaldi and Venuti (2003), defined for a 1.7 Ma eruption of the Bombarda volcano, Cyclades, Greece (massive to normally graded pumice and lithic breccia, even though pumices are very unusual in Crozon); and (3) the facies LT 2 of Martin et al. (2004), from the Cretaceous MIT Guyot, West Pacific (poorly sorted, structureless matrix-rich layers with volcanic and limestone clasts). The three facies were interpreted as proximal/medial (re)deposition facies of eruptive debris in a shallow submarine setting. Facies D consists of thin (from a few millimeters to a few centimeters in thickness) plane-parallel beds, with rare local cross-beddings. Sparse scoriaceous small blocks form overlying wave structures in the stratification (Fig. 8b). Facies D can be divided into two sub-facies. Sub-facies D1 (resembling facies B of Rinaldi and Venuti, 2003, but without erosive scours, and facies LT1 of Martin et al., 2004) consists of millimeter-sized abundant fluidal chloritic and sparse angular volcanic clasts in a mixed matrix, composed of ash, chlorite and bioclast-bearing siliceous patches (Fig. 4d, 5b). Subfacies D2, ressembling facies C of Rinaldi and Venuti (2003), is characterized by similar components in same proportions, but the lithic fragments are less than one millimeter in length. The beds are planar, wavy laminated or slightly convolute (Fig. 8b). Beds with internally discontinuous lenses are common, but cross bedding is an unusual feature. The elongated chloritic microclasts are in a parallel direction with the laminae (Fig. 4d). In the sample shown in Fig. 4d, there is a one-millimeter-wide load structure between each D2-type bed and its overlying D1-type bed.

\subsubsection{Calcareous conglomerate}

Above the BCD lithofacies association, the Aber seashore succession is continued with coarse peperitic breccias (facies E of Fig. 4e, f; see section 4.2.1.), then with conglomerate (facies F, Fig. 4g), which is exposed at the top of the Aber breccia pile. In a 
neighboring quarry, the conglomerate rests upon the bioclastic limestone beds L2 and it is laterally equivalent to a small number of pillow lavas (Fig. 3). This lithofacies F consists of volcanic and chloritic rounded pebbles, from millimeter to centimeter in length or diameter, associated with biogenic debris. Bioclasts are fragments of crinoids and brachiopods (Mélou, 1990). The volcanic clasts are plagioclase-phyric and the chloritic ones, probably derived from semi-consolidated mudstones, are generally vesicular. A few of these latter clasts also contain chloritoids (see later in the text) that attests to a greenschist metamorphism of the sedimentary rocks at their origin. The matrix is exclusively formed of biogenic microdebris and recrystallized calcite. Mélou (1990) assigned this part of the Rosan Formation, i.e. his level 16 above pillows in the same quarry, to Ashgill age, i.e. Cautleyan-Rawtheyan or upper Katian in the new international stratigraphic scale (Webby et al., 2004).

\subsection{Peperitic volcanic breccias}

Peperitic breccias are generated by mingling and fragmentation of magma in contact with typically wet sediment (White et al., 2000; Corsaro and Mazzoleni, 2002; Skilling et al., 2002b and references herein; Galerne et al., 2006). Fluidal peperite is characterized by the presence of lobate surfaces in the juvenile clasts, at any scale. Such lobate or fluidal clasts form through coarse mixing during fuel-coolant-interactions (FCIs), involving contact between a sediment-laden vaporisable liquid (impure coolant) and magma (fuel) (White, 1996; Hooten and Ort, 2002). Insulation, due to the persistence of a stable vapor-film between melt and water-rich sediment, allows the magma to develop complex globular form without, at least initially, undergoing brittle fragmentation (White, 1996; Martin and Németh, 2007). Thus, the lobate sills described in section 3.2. (as, to a lesser extent, the hypabyssal breccia of Kerdreux) can also be termed fluidal peperites. Peperitic breccias can contain blocky and/or 
fluidal juvenile clasts, the proportion of which is a function of several factors, such as the viscosity conditions during the cooling, the extent of wet sediment-magma mingling (Galerne et al., 2006), or the strain rate during explosions (higher rates will favor brittle clasts: Skilling, pers. comm., 2009).

In Crozon, the peperitic volcanic breccias divide into two main groups: chaotic peperitic breccias, containing near-spherical magmatic clasts up to $30 \mathrm{~cm}$ in diameter (Aber), and a sequenced and fining-up graded peperitic breccia, with volcanic clasts less than two centimeters in length (Lostmarc'h).

\subsubsection{Non-stratified peperitic breccias}

Above the BCD lithofacies association and below the F-type conglomerate, the Aber seashore displays a succession of coarse breccias enclosing fluidal magmatic clasts, termed facies E (Fig. 3). Sub-facies E1 consists of locally weakly graded breccia bearing fluidal magmatic and sediment-derived chloritic clasts, less than $2 \mathrm{~cm}$ in length (Fig. 4e). Only a few small magmatic clasts are angular. Sub-facies E2 is characterized by the presence of chloritic enclave-bearing near-spherical magmatic clasts up to $30 \mathrm{~cm}$ in diameter (Fig. 4f). The E2-type breccia is generally chaotic at the scale of the outcrops. One cross-section displays the passage from the E1- to the E2-type breccia. The matrix of both sub-facies is comparable. Highly fluidal chloritic fragments and fluidal/angular magmatic ones are surrounded by siliceous microbioclastic cement (Fig. 6c). Fragments of crinoids and bryozoa have also been recognized. Both fluidal chloritic and magmatic clasts enclose bioclastic fragments within their amoeboidal convolutions (Fig. 4f, 6c). Magmatic fragments are plagioclase-phyric. Most of the chloritic clasts are chloritoid rich (Fig. 4f, 6c), a feature characteristic of facies $\mathrm{E}$ and $\mathrm{F}$

(Fig. 3). The borders of the chloritic clasts are generally diffuse, as the chloritic material tends to mix with the bioclastic cement to produce a composite matrix. 


\subsubsection{Rhythmic fining-up graded peperitic breccia}

The Lostmarc'h Headland is mainly formed by pillow lavas and derived monomict breccia (facies G of Fig. 4h) within a calcareous matrix (see the next section). At the top of the Lostmarc'h volcanic succession, we observe an $8 \mathrm{~m}$-thick rhythmic succession of peperitic breccia sequences exhibiting well-developed, mainly closed-packed, fining-up graded bedding (facies $\mathrm{H}$ of Fig. 4i). Each graded sequence is made up of highly fluidal plagioclasephyric magmatic clasts, from one millimeter to two centimeters in length, within a bioclastic calcareous matrix. The clasts are systematically altered to chlorite. Most of them display rounded, curvilinear or finger-like margins (Fig. 6d). Sparse fragments also have angular morphologies. Each graded sequence has a thickness varying from a few centimeters to a few decimeters. The calcareous matrix contains biogenic fragments (crinoids, brachiopods, and bryozoans) cemented with recrystallized calcite. The graded breccia sequences are topped by the L3 bioclastic limestone bed (Fig. 3), the apparent thickness of which (ca. $5 \mathrm{~m}$ ) is a minimum value because the Ordovician succession is here interrupted by a thrust-fault (Fig. 1b). The contact between the breccia and the overlying limestone is irregular, contorted. Limestone can be found as enclaves within the breccia (Fig. 9a), and vice-versa. Dispersed fluidal magmatic clasts occur sporadically within the limestone near its basal contact.

\subsection{Pillow lavas and associated chaotic monomict breccia}

Basaltic pillow lavas occur in the Lostmarc'h Headland beneath the rhythmic peperitic breccia (facies $\mathrm{H}$ ), with a bioclastic calcareous matrix displaying petrographical and palaeontogical features close to those of the L3 limestone bed that overlies the H-type breccia (Figs 3 and 9b). The pillow lavas are locally entirely fragmented to form a chaotic monomict 
breccia (facies G: Fig. 4h; Fig. 9c). Some lobate or pillowed sills have intruded the G-type breccia (Fig. 9c). The monomict breccia shows no structure and is composed of both jigsawfit angular and arched fragments (Fig. 4h). Fig. 9d displays a lava block enclosing a calcitic plume issued from a thin carbonated level. Such a feature might denote locally intense carbonate vaporization as a result of the lava emplacement onto wet unconsolidated subaqueous carbonated sediment bed.

\section{Magma-sediment mingling processes}

To discuss the formation of the peperites described in sections 3 and 4.2, we distribute them within two groups: (1) intrusion-related peperites, i.e. peperites formed either at the contact between sills/dykes and sediment or by ductile disintegration of sills/dykes; (2) effusion-related peperites, i.e. peperites formed by disintegration of hot pillow lavas/lava flows. This subdivision is transversal with respect to the previous one used to describe the facies (hypabyssal versus volcanic products).

\subsection{Formation of the intrusion-related peperites}

\subsubsection{Hypabyssal breccia}

The Postolonnec cliffs expose normal faults which were used by magma to upraise before setting as sills. The Kerdreux breccia, typically structureless, lies at the contact between diabase and Postolonnec mudstones (see section 3.1). The breccia comprises angular coarse-grained diabase fragments and blocky/fluidal sediment-derived clasts, both locally enclosed by coherent fine-grained juvenile magma, sometimes fragmented into spherical clasts (Fig. 5b). The presence of siliceous nodules and quartz grains, together with distinctive 
fossils and typical sedimentary features, makes evident that the greatest part of the mud clasts came from the immediately surrounding Postolonnec Formation. The fluidal-shaped morphology of a number of them attests that the mud was semi- or unconsolidated. However, some sedimentary fragments have obviously another origin. The occurrence of andalusite within a few argillaceous clasts (Fig. 6a), unknown in the regional Lower Palaezoic succession, strongly suggests the incorporation into the breccia of components derived from deeper levels, and probably of Brioverian age.

The narrowness of the outcrop area, the fact that the breccia/mudstone contact is masked, which make impossible any characterization of the possible steepness of the contact - a key to infer or not the existence of a diatreme breccia (Ross et al., 2005; Auer et al., 2007; Lorenz and Kurszlaukis, 2007) - and the lack of other occurrences of such a facies in Crozon make unclear the significance of the breccia. We interpret the lack of organization of the breccia and the presence of both blocky and fluidal country-rock components together with juvenile clasts as a consequence of either (i) a pre-detonation coarse mixing of magma with sediment coolant ("frozen" FCI) associated with local phreatomagmatic disruption or (ii) a fragmentation induced by more general phreatomagmatic explosions in the root zone of the volcanic system (White, 1996).

\subsubsection{Sills and detached pillow-like lobes}

Sills intruding the Postolonnec and Kermeur sedimentary Formations or the overlying Rosan volcaniclastic succession display undulating lobate contacts (Fig. 7). They are generally associated with pillow-like lobes, still attached or not to their parent sill, exhibiting intimate sediment-magma mingling features (Fig. 5d, 7 inset). Such peperitic morphologies indicate an emplacement into a soft substrate (Skilling et al., 2002b). This implies that the oldest observed formation intruded by peperitic sills (i.e. the Postolonnec one dated as 
Llanvirn age) was incompletely lithified during the Ashgillian volcanism activity, about 15 Ma later (using the Ordovician timescale calibration proposed by Sadler and Cooper, 2004).

The pods characteristic of the E2-type breccia have near-spherical forms similar to the pillow-like lobes, and both contain numerous highly fluidal chloritic enclaves. The formation of both structures is thus likely comparable. They probably result from ductile disintegration of the coherent magma during its intrusion either into fine sediment (Martin and Németh, 2007) or into unconsolidated volcaniclastic breccia, rich in fine matrix. Such intrusions of peperitic pods into submarine polymict volcaniclastic breccia have also been proposed by Templeton and Hanson (2003) for Jurassic arc-apron metavolcanic deposits from Sierra Nevada in northern California.

A model of sill intrusion into soft BCD-type volcaniclastic breccias, followed by its progressive disintegration into pillow-like clasts, is depicted in Fig. 10. The host volcaniclastic material is remobilized and a fluidized halo forms around the sills. Fluidal magmatic fragments detach from the main body and mingle with the BCD-type breccias. The E2-type near-spherical clasts would correspond to a complete disintegration of the initial sills/dykes whereas the pillow-likes lobes observed at the tips of lobate sills (Fig. 7 inset) would reflect the initiation of the process, as shown in Fig. 10. The smaller peperitic clasts observed in the E1-type breccia would form similarly, but with a higher degree of disintegration, perhaps associated with local phreatomagmatic disruption (Martin and Németh, 2007).

Almost all the sills observed in Crozon and all the E2-type near-spherical clasts contain chloritic enclaves (Fig. 5f). These enclaves are fluidal and exhibit morphologies very similar to those of the fluidal mud clasts identified within the Kerdreux hypabyssal breccia. Some of them also resemble the inclusions of fluidal sandy matrix in igneous clasts described by Petry et al. (2007) in the Lower Cretaceous Paraná Basin peperites, southern Brazil (their 
Fig. 7). The presence of such fluidal enclaves cannot be easily explained. Their great amount (they represent more than 40 vol. \% in some diabases) and their occurrence in the central part of the largest intrusive bodies ( $>15 \mathrm{~m}$ thick) exclude incorporation of surrounding sediment, except near the contact. The possibility of introducing a great quantity of soft surrounding sediment into a large intrusion by passive incorporation during its progression should be rapidly limited by thermal and mechanical constraints (e.g., Bohrson and Spera, 2001; Costa et al., 2007; Petry et al., 2007). Similar fluidal sediment-derived fragments also occur within the matrix of BCDE-type breccias, interpreted as tephra (re)deposited into shallow submarine sediment. Subsurface thermohydraulic explosions, which fragment the semi- or unconsolidated country sediment, then incorporation of the resulting clasts first into explosive breccias, then into subsequent intrusive magmas passing through the brecciated zone might satisfactorily account for all the observed features (Auer et al., 2007). Most of the chloritic enclaves/clasts correspond probably to ancient argillites. This strongly suggests that the greatest part of them originates from the Kermeur and Postolonnec Formations, which are intruded by dykes and sills and directly underlie the submarine volcanisclastic deposits (Rosan Formation, Fig. 2). The chloritoid-bearing sediment-derived clasts typical of the Etype breccias might be interpreted as fragments from deeper Brioverian levels.

\subsection{Formation of the effusion-related peperites}

The pillow lavas from Lostmarc'h, together with the associated G-type monomict breccia, are overlain by the H-type graded peperitic breccia sequences (Fig. 3). The presence in this latter facies of numerous fluidal-shaped basaltic clasts, showing delicate finger-like structures (Fig. 6d), and the lack of cross-stratification definitely excludes any epiclastic remobilisation or pyroclastic phenomenon. Streamflow mechanisms, such as high bulk 
density mass flows, which may not have evidence of traction structures, could transport delicate clasts without damage (e.g. Allen and McPhie, 2001). However, such mechanisms would be unable to produce neither thin ordered sequences nor sinking structures as shown in Fig. 11 and discussed below in this section.

Waichel et al. (2007) have proposed a model in which the interaction between lavas flows and wet fine-grained sediments generates grossly graded fluidal peperite breccias. Below a massive lava flow, the mingling process forms non graded, closed-packed peperite close to the contact, then dispersed peperite toward the interior of the sediment layer. Such a model is nevertheless unable to explain the formation of the Lostmarc'h peperitic breccia, because 1) dispersed peperites are sparse, only observed at the contact with the overlying Porzhig limestone bed, and 2) the structure of the Lostmarc'h breccia sequences, graded and rhythmic, is much better-ordered than that of the central Paraná Flood Basalt peperites (Waichel et al., 2007).

The model proposed by Brown and Bell (2007) for the graded peperitic breccia from the Palaeogene Carraig Mhór Bed (CMB), Scotland, better fits with our own observations. These authors explain the formation of the $\sim 10 \mathrm{~m}$ thick stratiform, graded CMB through disintegration of basalt by mingling during flowing within wet, unconsolidated sediment, followed by settling of the largest clasts toward the base of each unit. Following Brown and Bell (2007), the vertical variation in clast morphology and size within the CMB developed as a consequence of magma being emplaced onto wet sediment, producing a sub-horizontal alignment of clasts. The magma behaved firstly in a ductile fashion, fragmented as large, fluidal-shaped clasts that sank through sediment. As heat began to dissipate from the system, magma-sediment interaction decreased and local collapses of the vapor-film at the meltsediment interfaces caused small explosions, quench-fracturing the lava into sub-angular clasts (Fig. 11a). In the Brown and Bell (2007) model, contrary to the Waichel et al. (2007) 
one, the causative flow is essentially consumed during the interaction. As shown in Fig. 11, such a model can be used to explain the formation of the Lostmarc'h peperitic breccia, with one notable difference: the small thickness of the graded sequences (a few centimeters/decimeters) is not consistent with disruption of thick lava flows. Entire brecciation of thin sheets of fluid lava, less than one meter thick, alike - but more pillowed than the continental pahoehoe sheet flows described by Hon et al. (1994), could more satisfactorily account for the observations. The presence of a lava block, $30 \mathrm{~cm}$ in diameter, isolated within limestone, with a train of small clasts dragged behind (Fig. 11b), is consistent with the hypothesis of sinking of the largest volcanic fragments into the lime mud after in situ brecciation. The contact between the pillow lavas (plus G-type monomict breccias) and the overlying rhythmic peperites is undulating and irregular. The passage from the first facies to the second one might correspond to a decline in the magmatic effusion rate. When the magma budget was high with respect to the sediment production, pillow lavas formed. When the magma budget decreased, thin pillowed lava sheets flowed onto the sediment surface separately from each other. They invaded the sediment, mingled with it, up to be entirely disintegrated. At the top of the Lostmarc'h section, the contact between the peperitic breccia and the Porzhig limestone (L3) is lobate and contorted too. In addition, volcanic fluidal clasts occur sparsely in the limestone bed. These features can be explained through peperitic contacts in a rich water environment setting. They do not imply any erosion period, with induration followed by karstification, as previously suggested by Paris et al. (1981). The Ashgill Porzhig limestone, quasi devoid of volcanic fragments, dates the end of the volcanic activity.

\section{Volcano structure and palaeoenvironment}


The Crozon outcrops are interpreted as a cross-section from the root to the sea floor through a fairly unusual soft-substrate volcanic system. The root zone displays polymict breccias in close proximity to intrusive rocks, normal faults, hydrothermal breccias, feeder dykes, and sills. The prevalence of fluidal sedimentary clasts within the hypabyssal breccia, in association with a few angular diabase fragments and juvenile magmatic clasts, is consistent with a phreatomagmatic process, involving water-rich unconsolidated sediment (White, 1996; Martin et al., 2007). The fluidal chloritic fragments occurring in the matrix of the volcaniclastic deposits, within the greatest part of the shallow sills and also within the sillderived pillow-like lobes can be interpreted as mud chunks split up by thermohydraulic explosions within the wet unconsolidated sediment. The occurrence of andalusite- and chloritoid-bearing argillaceous clasts in the A-, E-, and F-type breccias highly suggests that the corresponding fragments are issued from the deep pre-hercynian metamorphic substratum, probably Brioverian in age. Relative to the syn-eruptive surface, these clasts were come from a depth greater than $1500 \mathrm{~m}$ (Fig. 2).

The structural characteristics of the Crozon volcanic deposits on the palaeo-surface are not typical of those encountered in subaerial tuff rings (surge-dominated eruptions) or subaerial tuff cones (fallout-dominated eruptions). The volcaniclastics do not exhibit features such as impact structures, U-shaped channels or dune/antidune beddings (Auer et al., 2007). Lack of impact sags is good evidence of subaqueous emplacement, though there is some depth of very shallow water in which sags could still form (e.g. Sohn and Park, 2005). Likewise, no indication of emergent surtseyan eruption has been found in Crozon: alternation of cross-stratified beds with discontinuous laminae, indicative of pyroclastic surges, and/or regular beds of even thickness with continuous internal stratification, suggestive of subaerial tephra fallout (White and Houghton, 2000; Cole et al., 2001). 
The presence of fossiliferous marine beds throughout the stratigraphic succession of Crozon is indicative of submarine environment. Although water depth of the depositional setting is not easy to constrain, the three calcareous levels L1, L2, and L3 (Fig. 3), located at key positions in the volcanic succession of Rosan, offer valuable pieces of information on the deposit environment and water depth. At the base of the Aber volcanic succession, the non reworked oolithic iron bed (base of the L1 level) is a condensed layer, probably quite deep at the end of the condensation. The overlying calcareous shell bed (summit of the L1 level) gives evidence of the development of a shelf benthic fauna, with the first significative occurrence of bryozoa. The L2 limestone beds are located between the E-type peperitic breccias and the F-type conglomerate at the Aber site. They contain a great amount of noneroded, non-fragmented but disarticulated large brachiopod shells. This taphonomic grade is usually related to the upper offshore, between the fair weather wave base and the storm wave base (Botquelen et al., 2006). The hummocky cross stratifications identified a few meters below in the Aber section are characteristic of the proximal upper offshore (30-60 m). Finally, in the thick bioclastic L3 limestone bed which seals the effusive activity at Lostmarc'h, the association of bryozoa and crinoids suggests a deepening of the environment with respect to that characterized by brachiopod assemblages, as the L2 level or comparable Moroccan occurrences (Alvaro et al., 2007).

The main non-peperitic volcanic breccias from Crozon (the BCD lithofacies association and the material surrounding the peperitic clasts in the lithofacies E) display features consistent with submarine deposition following phreatomagmatic eruptions, as the examples of Greek rhyolitic volcanoes described by Allen and McPhie (2000) and Rinaldi and Venuti (2003) or the example of the shallow-marine MIT Guyot (Martin et al., 2004): interbedding of weakly normally graded lapilli beds (faciès B/C) with sequences of planeparallel ash-rich laminae (facies D) and presence of fossiliferous sediment within the breccias. 
The abundance of highly vesicular clasts in the BCD succession is consistent with the hypothesis of emplacement at a relatively low depth. We interpret the facies $\mathrm{B} / \mathrm{C}$ either as the deposits of water-supported gravity mass flows derived from the collapse of subaqueous primary volcanic piles (Rinaldi and Venuti, 2003) and/or as the result of high concentration suspension sedimentation derived from subaqueous concentrated tephra jets (Chough and Sohn, 1990; Martin et al., 2004). The C-type breccias containing armored lapilli are inferred to have been formed in subaqueous conditions from a steam envelope that developed above the vent due to magma-water interaction (White and Houghton, 2000; Martin et al., 2004). Facies D could be the product of dilute flows or turbidity currents around the periods of eruptive rest (Martin et al., 2004). Occasionally, bloc settlings perturbed the beddings.

The Crozon volcano(es) resulting from explosive interaction with subsurface and surface water had probably the structure of one (or several) subaqueous tuff cone(s) (vigorous magmatic injection, persistent interaction of magma with sediment-laden coolant, explosivity, shallow surface water, infrequent surges: White, 1996; Sohn and Park, 2005). If subaqueous eruption within a soft-sediment environment is unlikely to produce a highly positive constructive volcanic form, as suggested by Belousov and Belousova (2001), the lack of curved contacts and truncated beds and the absence of abrupt changes in dip inclination within the Crozon volcaniclastic succession do not allow proposing a negative form either (crater), as Martin et al. (2004) do for the MIT Guyot. Seamounts, which are isolated steep cone-shaped volcano, usually found rising from a seafloor of 1000-4000 m depth, and guyots, flat-topped seamounts, are deep-sea volcano structures and thus cannot be invoked here. Tuff rings (maars) correspond exclusively to subaerial phreatomagmatic landforms (White, 1996).

A schematic illustration of the Crozon volcanic system during the first stages of its activity is represented in Fig. 12a. The depicted processes are thought to have formed the Atype hypabyssal breccia (Kerdreux), the groundlevel volcaniclastic succession (BCD 
lithofacies association of Aber) and the intrusive peperites (E-type breccias and intrusions from Postolonnec/Aber). Dykes and sills intruded the surrounding soft substrate and the volcaniclastic deposits after they had incorporated sedimentary bits in the course of their progression. The morphology of the peperitic intrusions at different palaeo-depths suggests that the substrate was less hydrated and more cemented deep down, but not completely lithified. Pillow-lavas, associated monomict G-type breccia and H-type effusive peperitic breccia postdate these events (Fig. 12b).

Occurrence of both tholeiitic and alkalic volcanism in restricted continental areas, sometimes in a single edifice, is typical of magmatism either in active continental rift zones (e.g., Bailey, 1983; Kabeto et al., 2001; Lustrino et al., 2002) or in already rifted passive margins (Maury et al., 2003). This latter palaeogeographic context is in good agreement with the tectonic and sedimentary scenario proposed by Hammann (1992, p. 45), where rifting takes place during the Ordovician in front of the North Gondwanan shelf, including the Armorican Massif. This event initiates the opening of the Rheic Ocean, then marked by Ashgillian volcanic episodes along the Gondwanan passive margin.

In the Crozon Peninsula, the development of carbonate sedimentation appears to be synchronous with the volcanic episode. The situation is comparable in the Central Iberian Domain (Buçaco Syncline, Portugal), where some sections expose tuffs, breccias, and sills in similar lithostratigraphic positions (Paris, 1981; Young, 1988). The resemblances between the Crozon and Buçaco Ordovician successions have already been shown by several authors (compiled in Robardet et al., 1990), based on sedimentary events and conspecific benthic faunas. The study of the Upper Ordovician in the Buçaco Syncline is in progress to compare precisely both volcanic systems and provide new arguments for strict continuity or not.

\section{Acknowledgements}


Detailed and constructive comments by Drs Ian Skilling and Karoly Németh helped us a lot to improve the manuscript. We also thank Dr Lionel Wilson for his editorial assistance. This is the contribution $\mathrm{n}^{\circ} \mathrm{xx}$ of the IUEM, European Institute for Marine Studies (Brest, France).

\section{References}

Allen, S.R., McPhie, J., 2000. Water-settling and resedimentation of submarine rhyolitic pumice at Yali, eastern Aegean, Greece. J. Volcanol. Geotherm. Res. 95, 285-307. Allen, S.R., McPhie, J., 2001. Syn-eruptive chaotic breccia on Kos, Greece, associated with an energetic pyroclastic flow. Bull. Volcanol. 63, 421-432.

Alvaro, J.J., Vennin, E., Villas, E., Destombes, J., Vizcaïno, D., 2007. Pre-Hirnantian (latest Ordovician) benthic community assemablges: Controls and replacements in a siliciclastic-dominated platform of the eastern Anti-Atlas, Morocco. Palaeogeog. Palaeoclimatol. Palaeoecol. 245, 20-36.

Auer, A., Martin, U., Németh, K., 2007. The Fekete-hegy (Balaton Highland Hungary) « softsubstrate » and « hard-substrate » maar volcanoes in an aligned volcanic complex Implication for vent geometry, subsurface stratigraphy and the palaeoenvironmental setting. J. Volcanol. Geotherm. Res. 159, 225-245.

Bailey, D.K., 1983. The chemical and thermal evolution of rifts. Tectonophysics 94, 585-597.

Belousov, A., Belousova, M., 2001. Eruptive process, effect and deposits of the 1996 and the ancient basaltic phreatomagmatic eruptions in Karymakoye lake, Kamchatka, Russia. Int. Assoc. Sedimentol. Spec. Publ. 30, 35-60. 
Bohrson, W.A., Spera, F.J., 2001. Energy-constrained open-system magmatic processes II: Application of Energy-Constrained Assimilation-Fractional Crystallization (EC-AFC) model to magmatic systems. J. Petrol. 42, 1019-1041.

Bourahrouh, A., 2002. Chitinozoaires et palynomorphes de l'Ordovicien supérieur nordgondwanien: impact de la glaciation ashgillienne. Thesis, University of Rennes 1, 300 pp.

Botquelen, A., Gourvennec, R., Loi, A., Pillola, G.L., Leone, F., 2006. Replacements of benthic associations in a sequence stratigraphic framework, examples from Upper Ordovician of Sardinia and Lower Devonian of the Massif Armoricain. Palaeogeog. Palaeoclimatol. Palaeoecol. 239, 286-310.

Brown, D.J., Bell, B.R., 2007. How do you grade peperites? J. Volcanol. Geotherm. Res. 159, 409-420.

Chauris, L., Plusquellec, Y., 1975. Carte géologique de la France (1/50000), feuille Douarnenez. Orléans : BRGM. Notice explicative par Chauris, L., Plusquellec, Y. (Editors) $25 \mathrm{pp}$.

Chauris, L., Plusquellec, Y., 1979. Carte géologique de la France (1/50000), feuille Brest. Orléans : BRGM. Notice explicative par Chauris, L., Plusquellec, Y. (Editors) 52 pp. Chough, S.K., Sohn, Y.K., 1990. Depositional mechanics and sequences of base surges, Songaksan tuff ring, Cheju Island, Korea. Sedimentology 37, 1115-1136.

Cole, P.D., Guest, J.E., Duncan, A.M., Pacheco, J.-M., 2001. Capelinhos 1957-1958, Faial, Azores: deposits formed by an emergent surtseyan eruption. Bull. Volcanol. 63, 204220.

Corsaro, R.A., Mazzoleni, P., 2002. Textural evidence of peperites inside pillow lavas at Acicastello Castle Rock (Mt. Etna, Sicily). J. Volcanol. Geotherm. Res. 114, 219-229. 
Costa, A., O. Melnik, Vedeneeva, E., 2007. Thermal effects during magma ascent in conduits, J. Geophys. Res., 112, B12205, doi:10.1029/2007JB004985.

Dabard, M.-P., Loi, A., Paris, F., 2007. Relationship between phosphogenesis and sequence architecture: Sequence stratigraphy and biostratigraphy in the Middle Ordovician of the Armorican Massif (NW France). Palaeogeog. Palaeoclimatol. Palaeoecol. 248, 339-356.

Darboux, J.R., Rolet, J., 1979. Mise en évidence d'unités hercyniennes différenciées dans le domaine centre-armoricain occidental: rapprochements? Recouvrements ? $7^{\mathrm{e}}$ Réunion Annuelle des Sciences de la Terre, Lyon, 143 (abstract).

Fortey, R.A., Harper, D.A.T., Ingham, J.K., Owen, A.W., Rushton, A.W.A., 1995. A revision of Ordovician series and stages from the historical type area. Geol. Mag. 132, 15-30.

Galerne, C., Caroff, M., Rolet, J., Le Gall, B., 2006. Magma-sediment mingling in an Ordovician rift basin: The Plouézec-Plourivo half-graben, Armorican Massif, France. J. Volcanol. Geotherm. Res. 155, 164-178.

Hammann, W., 1992. The Ordovician trilobites from the Iberian Chains in the Province of Aragon, NE-Spain. I. The trilobites of the Cystoid Limestone (Ashgill Series). Beringeria 6, 1-220.

Hon, K., Kauahikaua, J., Denlinger, R., Mackay, K., 1994. Emplacement and inflation of pahoehoe sheet flows: Observations and measurements of active lava flows on Kilauea Volcano, Hawaii. Geol. Soc. Am. Bull. 106, 351-370.

Hooten, J.A., Ort, M.H., 2002. Peperite as a record of early stage phreatomagmatic fragmentation processes: an example from the Hopi Buttes Volcanic Field, Navajo Nation, Arizona, USA. J. Volcanol. Geotherm. Res. 114, 95-106.

Juteau, T., Nonnotte, P., Jegou, I., Lamour, M., Naour, T., Cotten, J., 2007. Le volcanisme sous-marin d'âge ordovicien supérieur de la presqu'île de Crozon (Finistère). Etude des processus de bréchification. Bull. Soc. géol. minéral. Bretagne (D) 4, 1-67. 
Kabeto, K., Sawada, Y., Iizumi, S., Wakatsuki, T., 2001. Mantle sources and magma-crust interactions in volcanic rocks from the northern Kenya rift: geochemical evidence. Lithos 56, 111-139.

Lorenz, V., Kurszlaukis, S., 2007. Root zone processes in the phreatomagmatic pipe emplacement model and consequences for the evolution of maar-diatreme volcanoes. J. Volcanol. Geotherm. Res. 159, 4-32.

Lustrino, M., Melluso, L., Morra, V., 2002. The transition from alkaline to tholeiitic magmas: a case study from the Orosei-Dorgali Pliocene volcanic district (NE Sardinia, Italy). Lithos 63, 83-113.

Martin, U., Breitkreuz, C., Egenhoff, S., Enos, P., Jansa, L., 2004. Shallow-marine phreatomagmatic eruptions through a semi-solidified carbonate platform (ODP Leg 144, Site 878, Early Cretaceous, MIT Guyot, West Pacific). Mar. Geol. 204, 251-272.

Martin, U., Németh, K., 2007. Blocky versus fluidal peperite textures developed in volcanic conduits, vents and crater lakes of phreatomagmatic volcanoes in Mio/Piocene volcanic fields of Western Hungary. J. Volcanol. Geotherm. Res. 159, 164-178.

Martin, U., Németh, K., Lorenz, V., White, J.D.L. (Editors), 2007. Maar-diatreme volcanism and associated processes. J. Volcanol. Geotherm. Res. Special Issue 159, 312 pp.

Maury, R.C., Béchennec, F., Cotten, J., Caroff, M., Cordey, F., Marcoux, J., 2003. Middle Permian plume-related magmatism of the Hawasina Nappes and the Arabian Platform: Implications on the evolution of the Neotethyan margin in Oman. Tectonics 22, doi:10.1029/2002TC001483.

McPhie, J., 1995. A Pliocene shoaling basaltic seamount: Ba Volcanic Group at Rakiraki, Fiji. J. Volcanol. Geotherm. Res. 64, 193-210.

Mélou, M., 1990. Brachiopodes articulés de la coupe de l'île de Rosan (Crozon, Finistère). Formation des tufs et calcaires de Rosan (Caradoc-Ashgill). Geobios 23, 539-579. 
Németh, K., Martin, U., 2007. Shallow sill and dyke complex in western Hungary as a possible feeding system of phreatomagmatic volcanoes in "soft-rock" environment. J. Volcanol. Geotherm. Res. 159, 138-152.

Paradis, S., Velde, B., Nicot, E., 1983. Chloritoid-pyrophyllite-rectorite facies rocks from Brittany, France. Contrib. Mineral. Petrol. 83, 342-347.

Paris, F., 1981. Les Chitinozoaires dans le Paléozoïque du Sud-Ouest de l'Europe (Cadre géologique - Etude systématique - Biostratigraphie). Mém. Soc. géol. minéral. Bretagne $26,1-411$

Paris, F., 1990. The Ordovician chitinozoan biozones of the Northern Gondwana Domain. Rev. Palaeobot. Palynol. 66, 181-209.

Paris, F., Pelhate A., Weyant, M., 1981. Conodontes ashgilliens dans la Formation de Rosan, coupe de Lostmarc'h (Finistère, Massif Armoricain). Conséquences paléogéographiques. Bull. Soc. géol. minéral. Bretagne (C) 13, 15-35.

Paris, F., Robardet, M., Dabard, M.-P., Ghienne, J.-F., Guillocheau, F., Le Hérissé, A., Loi, A., Mélou, M., Feist, R., Servais, T., Shergold, J., Vidal, M., Vizcaïno, D., 1999. Ordovician sedimentary rocks of France. Short papers of the $8^{\text {th }}$ ISOS, Prague, June 2025, Acta Universitatis Carolinae, Geologica 43, pp. 85-88.

Pearce, J.A. and Cann, J.R., 1973. Tectonic setting of basic volcanic rocks determined using trace element analysis. Earth Planet. Sci. Lett. 19, 290-300.

Petry, K., Jerram, D.A., del Pilar M. de Almeida, D., Zerfass, H., 2007. Volcanic-sedimentary features in the Sierra Geral Fm., Paraná Basin, southern Breazil: Exemples of dynamic lava-sediment interactions in an arid setting. J. Volcanol. Geotherm. Res. 159, 313-325. Plusquellec, Y., Rolet, J., Darboux, J.R., 1999. Notice explicative de la feuille Châteaulin à 1/50000. Carte géologique de la France, BRGM, 157 pp. 
Rinaldi, M., Venuti, M.C., 2003. The submarine eruption of the Bombarda volcano, Milos Island, Cyclades, Greece. Bull. Volcanol. 65, 282-293.

Robardet, M., Bonjour, J.L., Paris, F., Morzadec, P., Racheboeuf, P.R., 1994. Ordovician, Silurian and Devonian of the Medio-North-Armorican Domains. In : Keppie, J.D. (Ed.), Pre-Mesozoic Geology in France and Related Areas. Springer Verlag, pp. 142-151.

Robardet, M., Paris, F., Racheboeuf, P.R., 1990. Palaeogeographic evolution of southwestern Europe during Early Palaeozoic times. In: McKerrow, W.S., Scotese, C.R. (Editors), Palaeozoic Palaeogeography and Biogeography. Geological Society Memoir 12, pp. 411-419.

Rolet, J., Darboux, J.R., Chevalier, Y., 1984. La cicatrice Crozon Nord - Crozon Sud (Finistère) est jalonnée de volcanites et basites grenues en lambeaux. $10^{\mathrm{e}}$ Réunion Annuelle des Sciences de la Terre, Bordeaux, 481 (abstract).

Rolet, J., Le Gall, B., Darboux, J.R., Thonon, P., Gravelle, M., 1986. L’évolution géodynamique dévono-carbonifère de l'extrémité occidentale de la chaîne hercynienne d'Europe sur le transect Armorique-Cornwall. Bull. Soc. géol. France 8, 43-54.

Ross, P.-S., Ukstins Peate, I., McClintock, M.K., XU, Y.G., Skilling, I.P., White, J.D.L., Houghton, B.F., 2005. Mafic volcaniclastic deposits in flood basalt provinces: A review. J. Volcanol. Geotherm. Res. 145, 281-314.

Sadler, P.M., Cooper, R.A., 2004. Calibration of the Ordovician Timescale. In: Webby, B.D., Paris, F., Droser, M., Percival, I. (Editors), The Great Ordovician Diversification Event. Columbia University Press, New York, pp. 48-51.

Skilling, I.P., White, J.D.L., McPhie, J. (Editors), 2002a. Peperite: Processes and Products of Magma-Sediment Mingling. J. Volcanol. Geotherm. Res. Special Issue 114, 249 pp.

Skilling, I.P., White, J.D.L., McPhie, J., 2002b. Peperite: a review of processes and products. J. Volcanol. Geotherm. Res. 114, 1-17. 
Sohn, Y.K., Park, K.H., 2005. Composite tuff ring/cone complexes in Jeju Island, Korea: possible consequences of substrate collapse and vent migration. J. Volcanol. Geotherm. Res. 141, 157-175.

Templeton, J.H., Hanson, R.E., 2003. Jurassic submarine arc-apron deposits and associated magma/wet-sediment interaction, northern Sierra Nevada, California. J. Volcanol. Geotherm. Res. 128, 299-326.

Waichel, B.L., de Lima, E.F., Sommer, C.A., Lubachesky, R., 2007. Peperite formed by lava flows over sediments: An example from the central Paraná Continental Flood Basalts, Brazil. J. Volcanol. Geotherm. Res. 159, 343-354.

Webby, B.D., Cooper, R.A., Bergström, S.M., Paris, F., 2004. Stratigraphic framework and time slices. In: Webby, B.D., Paris, F., Droser, M., Percival, I. (Editors), The Great Ordovician Diversification Event. Columbia University Press, New York, pp. 41-47.

White, J.D.L., 1991. The depositional record of small, monogenetic volcanoes within terrestrial basins. In: Fisher, R.V., Smith, G.A. (Editors), Sedimentation in Volcanic Settings. Society for Sedimentary Geology, Tulsa (Oklahoma), pp. 155-171.

White, J.D.L., 1996. Impure coolants and interaction dynamics of phreatomagmatic eruptions. J. Volcanol. Geotherm. Res. 165, 1-17.

White, J.D.L., Houghton, B.F., 2000. Surtseyan and related eruptions. In: Sigursson, H., Houghton, B., McNutt, S., Rymer, H., Stix, J. (Eds), Encyclopedia of volcanoes. Academic Press, New York, pp. 495-512.

White, J.D.L., McPhie, J., Skilling, I.P., 2000. Peperite: a useful genetic term. Bull. Volcanol. $62,65-66$

Wohletz, K., 2002. Water/magma interaction: some theory and experiments on peperite formation. J. Volcanol. Geotherm. Res. 114, 19-35. 
Young T.P., 1988. The lithostratigraphy of the upper Ordovician of central Portugal. J. Geol. Soc. London 145, 377-392. 


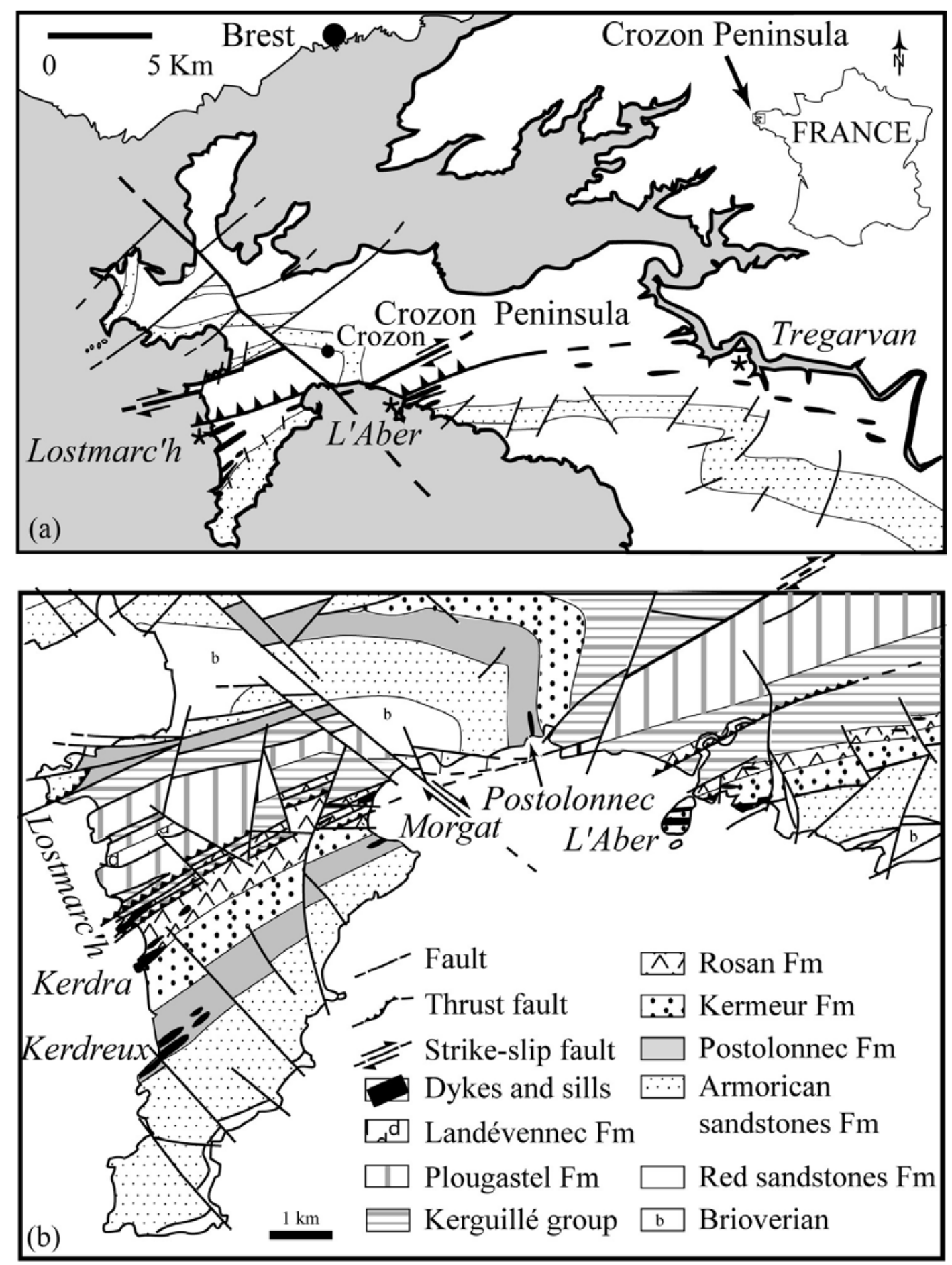

Fig. 1. Geological maps and location of the studied outcrops. (a) Simplified structural sketch of the Crozon Peninsula (Armorican Massif, France). (b) Geological map of the southern part of the Crozon Peninsula (modified after Chauris and Plusquellec, 1975, 1979), with location of the volcanic outcrops. 


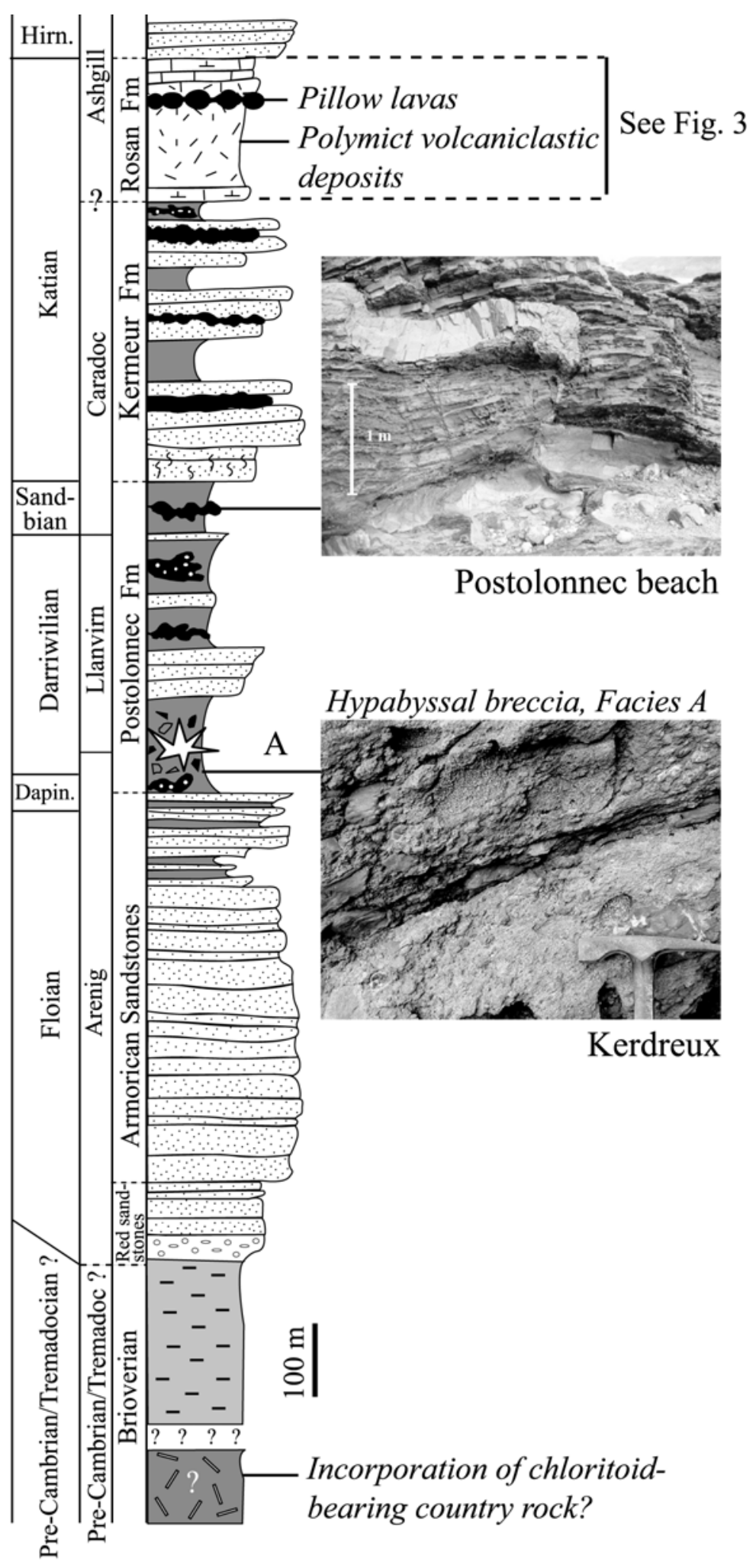

Fig. 2. Lithostratigraphic column of the southern part of the Crozon Peninsula, up to the end of the Ordovician, with global and British stratigraphic stages (assigned from Paris, 1990; Bourahrouh, 2002; and Webby et al., 2004). The (non-graduated) x-axis correlates schematically to grain size. 


\section{Aber}

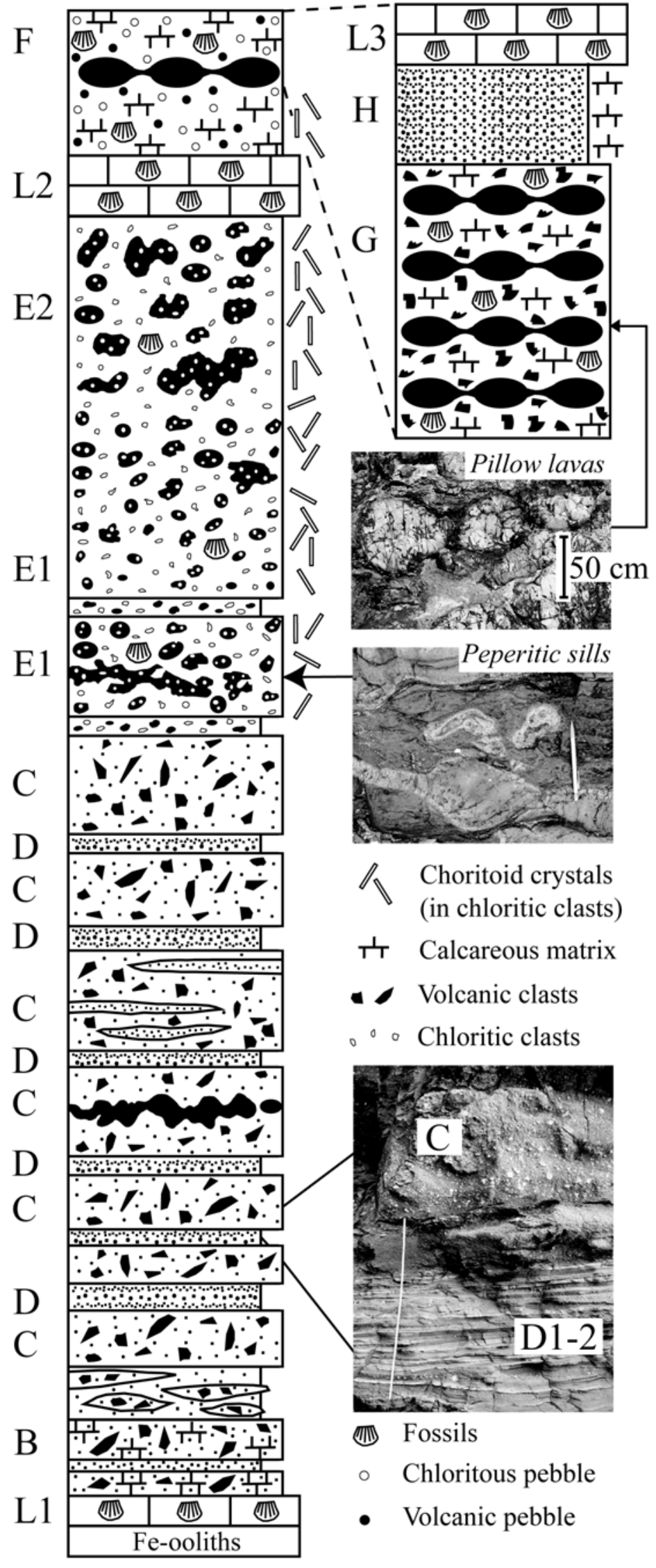

Fig. 3. Lithostratigraphic column showing the Ashgillian volcanic succession from Crozon (Rosan Formation) at the Aber and Lostmarc'h sites. Letters along the left side denote the facies as defined in Fig. 4. L1, L2, and L3 correspond to three calcareous bioclastic levels, located at key positions in the volcanic succession of Rosan, which offer pieces of information on the deposit environment and water depth (see text). Grain size (x-axis) is schematic.

Photographs illustrate some details of the succession. 

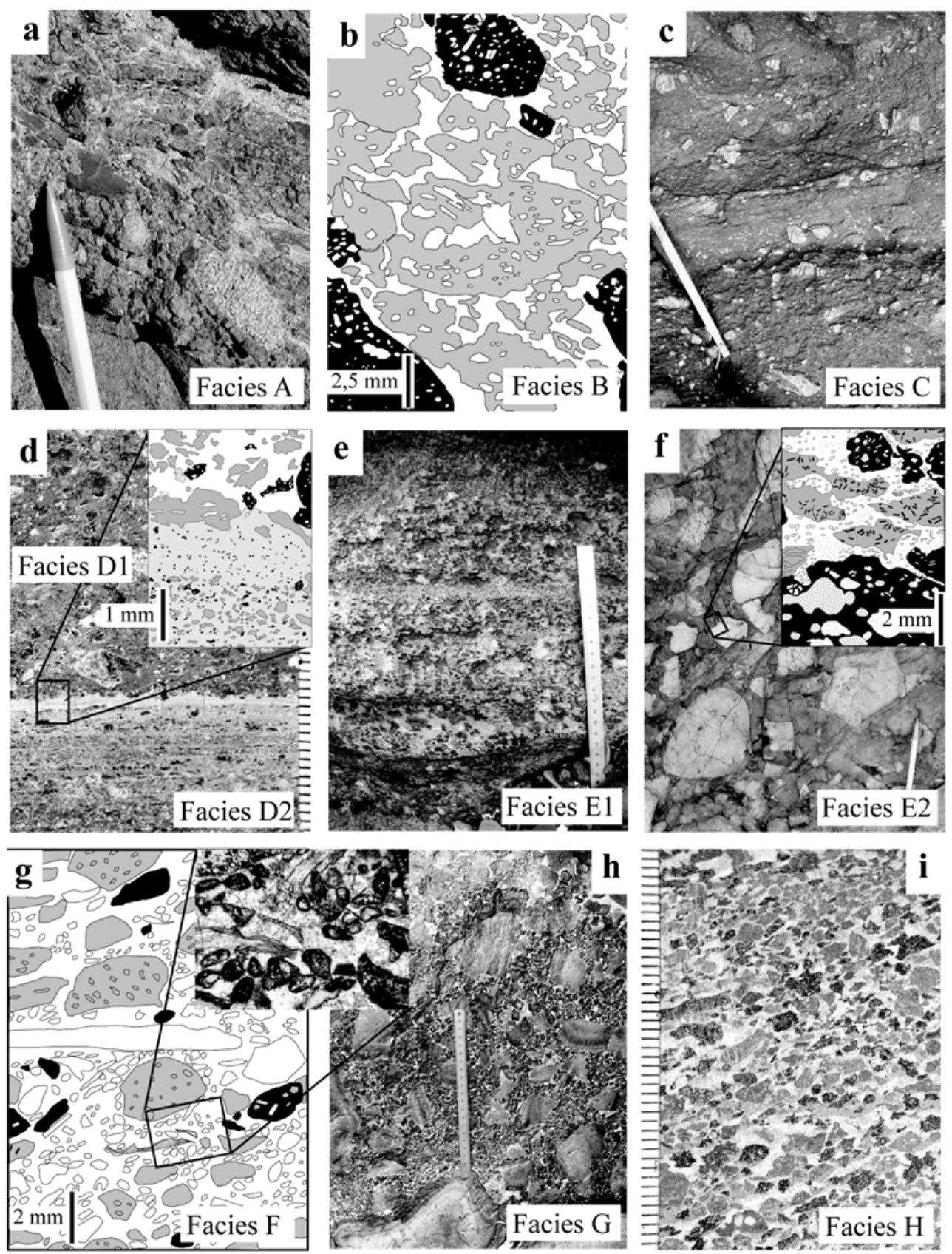

Fig. 4. Photographs and sketches illustrating the volcaniclastic facies of Crozon. (a) Hypabyssal polymict breccia from Kerdreux (facies A). Pen for scale. (b) Drawing (from a thin-plate microphotograph) of details of the crudely stratified volcaniclastic deposits from Aber with fine calcareous bioclastic matrix (faciès B). Black: lava clasts; grey: sedimentderived chloritic clasts; white: calcareous matrix. (c) Crudely stratified volcaniclastic deposits from Aber with silicic matrix (facies C). $20 \mathrm{~cm}$-long rule for scale. (d) Thin-bedded volcaniclastic deposits from Aber (facies D). One graduation for one millimeter. Inset: drawing (from a thin-plate microphotograph) of the contact between sub-facies D1 (lithic fragments $<1 \mathrm{~cm}$ in length; planar matrix-poor beds) and D2 (lithic fragments $<1 \mathrm{~mm}$ in length; planar, wavy or convolute matrix-rich beds; elongated volcanic microclasts in a parallel direction with the laminae; mm-sized load structures). Black: lava clasts; dark grey: sediment-derived chloritic clasts; pale grey: fine composite matrix; white: bioclastic matrix. (e) Weakly graded peperitic breccia from Aber bearing fluidal (sediment-derived) chloritic 
and volcanic clasts less than $2 \mathrm{~cm}$ in length within a bioclastic matrix (sub-facies E1). $20 \mathrm{~cm}$ long rule for scale. (f) Non-stratified peperitic breccias from Aber with near-spherical magmatic clasts up to $30 \mathrm{~cm}$ in diameter (sub-facies E2). Matrix corresponds to the sub-facies E1. Pen for scale. Inset: drawing (from a thin-plate microphotograph) of the contact between a near-spherical magmatic clast and the composite E1-type matrix. Black: magmatic clasts; grey: chloritoid-rich sediment-derived chloritic clasts; white: bioclastic matrix. (g) Drawing (from a thin-plate microphotograph) of details of the Aber/Rosan calcareous conglomerate, bearing centimeter-sized volcanic and vesicular sediment-derived chloritic rounded pebbles, associated with crinoid and brachiopod debris (facies F). Black: lava pebbles; grey: sedimentderived chloritic pebbles; white: calcareous bioclasts. Inset: microphotograph of an area rich in bioclasts. The long chips are brachiopod fragments. (h) Pillow-lava-derived chaotic monomict breccia from Lostmarc'h (facies G). $20 \mathrm{~cm}$-long rule for scale. (i) Peperitic breccia from Lostmarc'h exhibiting repeated fining-up graded sequences, and comprising highly fluidal plagioclase-phyric volcanic clasts within a bioclastic calcareous matrix (facies $\mathrm{H}$ ). Scale is graduated in millimeters. 

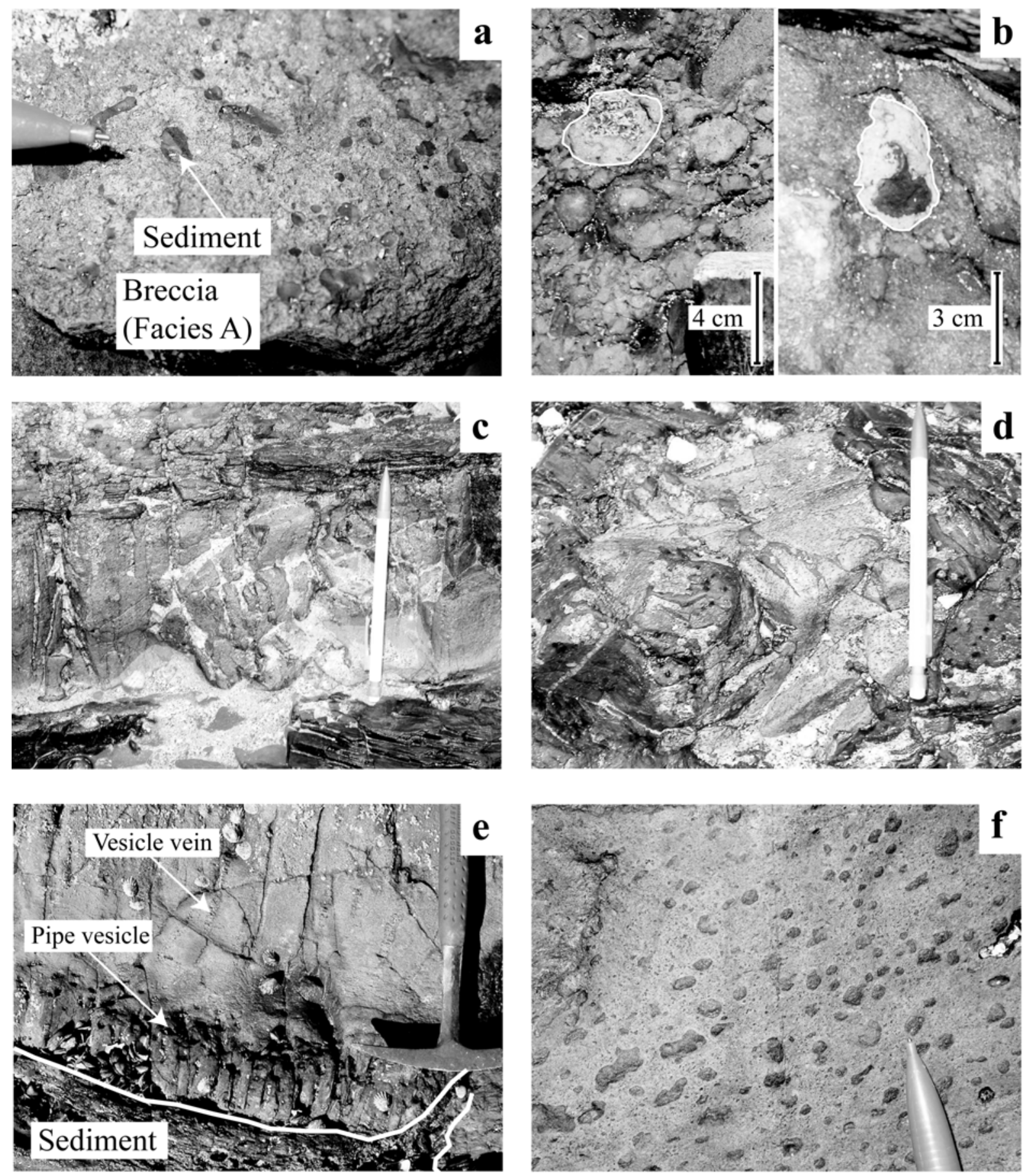

Fig. 5. Examples of sedimentary incorporation within magmatic breccias or bodies. (a) Ancient mud chunks within the hypabyssal breccia from Kerdreux (Facies A of Fig. 4a). Pen for scale. (b) Fine-grained magmatic fluidal clasts having a core formed by a coarse-grained magmatic fragment or a sedimentary argillaceous one. (c) Sediment invading cooling cracks of a sill from the Postolonnec site. Pen for scale. (d) Isolated amoeboid pillow-like lobe from the Postolonnec site, including fluidal sedimentary enclaves. Pen for scale. (e) Pipe vesicles and vesicle veins at the base of a sill in the Kermeur Formation, Aber site. Hammer for scale. (f) Fluidal sediment-derived chloritic enclaves within a sill from Aber. Pen for scale. 

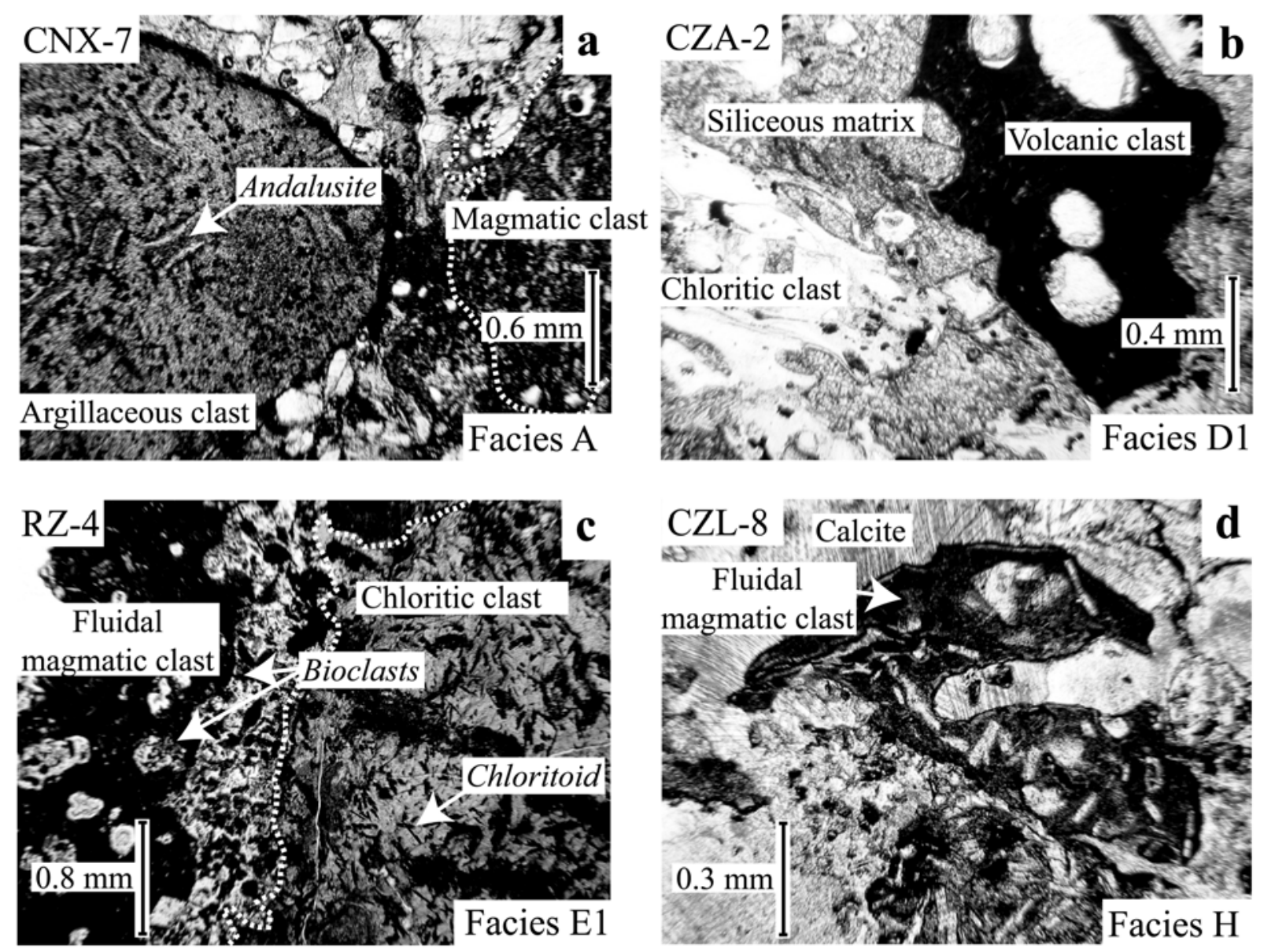

Fig. 6. Photomicrographs of Crozon breccia lithofacies. (a) Andalusite within an argillaceous clast in the hypabyssal breccia from Kerdreux (facies A of Fig. 4a). (b) Detail of a sample of the thin-bedded volcaniclastic breccia from Aber (sub-facies D1 of Fig. 4d). (c) Detail of a sample of the weakly graded peperitic breccia from Aber (sub-facies E1 of Fig. 4e). Note the presence of chloritoid within the chloritic clasts. (d) Plagioclase-bearing fluidal volcanic clast within the peperitic breccia from Lostmarc'h (Facies H of Fig. 4i).

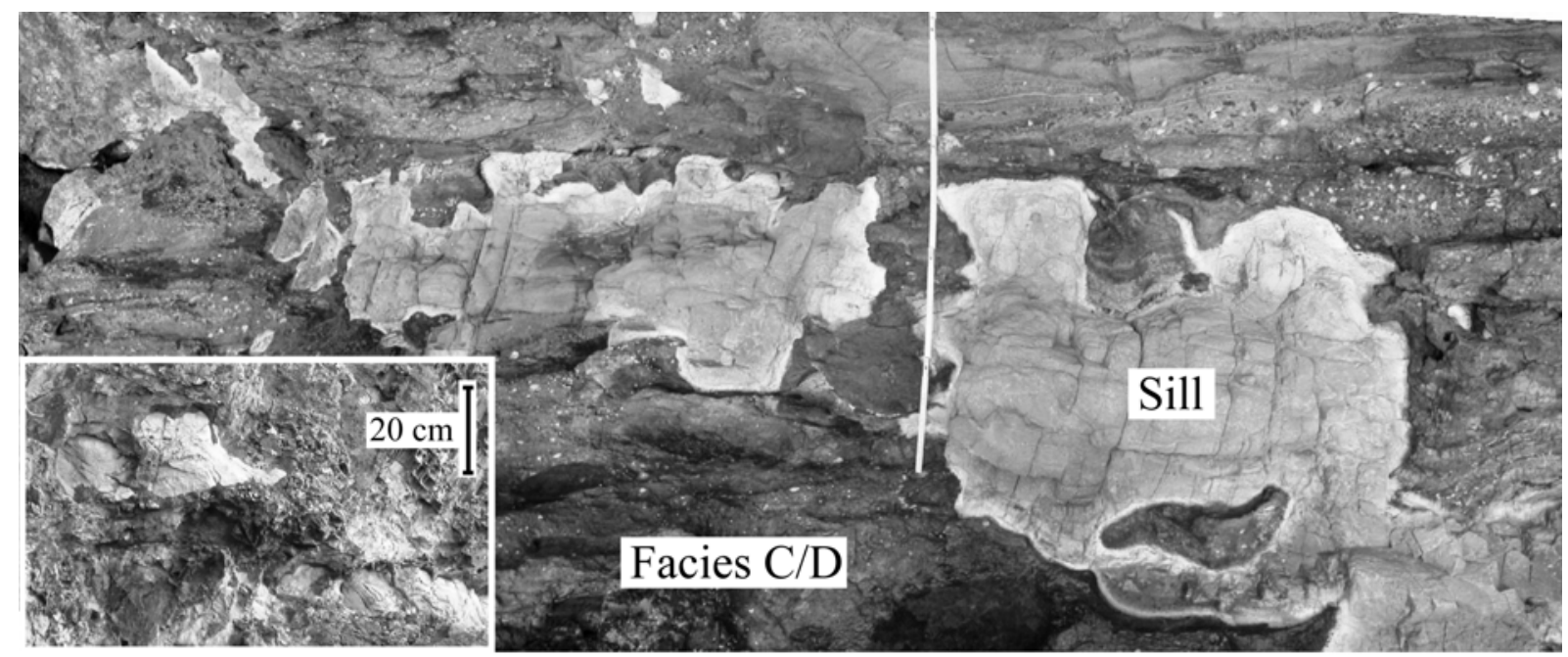

Fig. 7. Photomontage showing a lobate peperitic sill intruded into the $C / D$ volcaniclastic lithofacies (Rosan Formation, Aber). Length of the rule: $80 \mathrm{~cm}$. Inset: pillow-like lobes at a sill tip. 

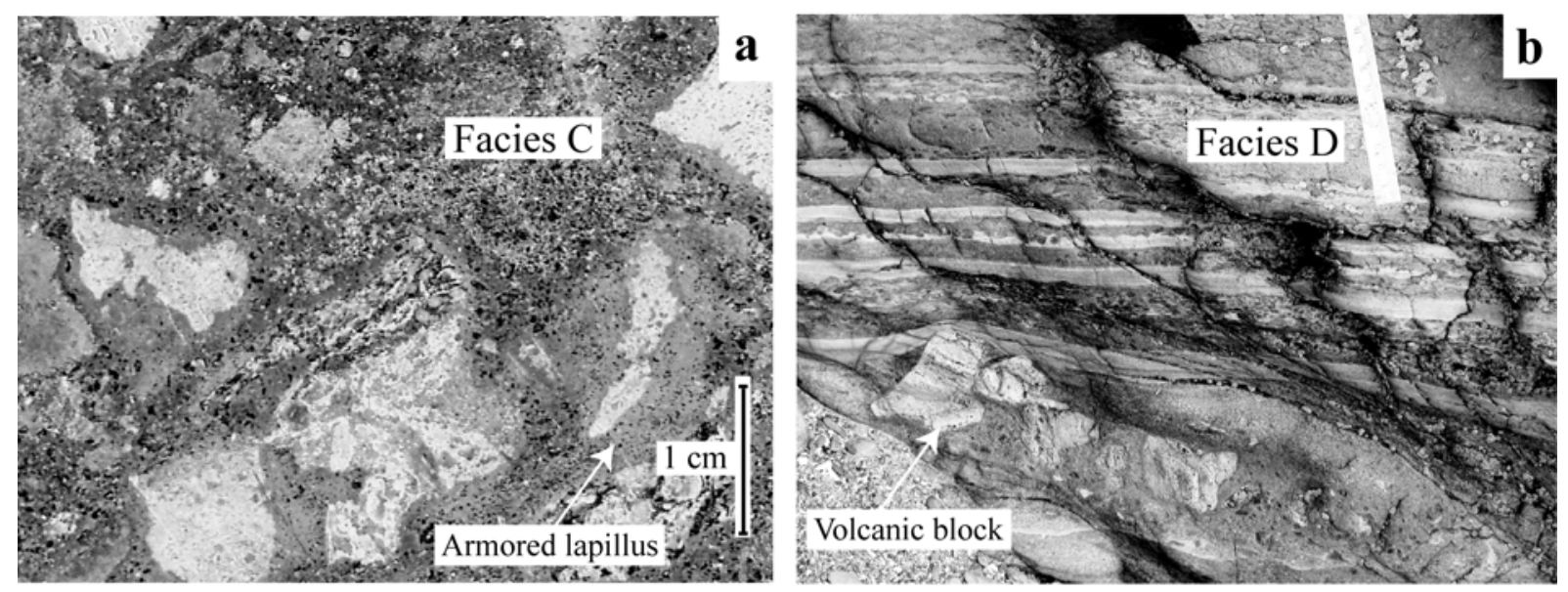

Fig. 8. Detail of the volcaniclastic breccias from Aber. (a) Armored lapilli in the C-type breccia, formed by lapilli-sized volcanic rock fragments concentrically coated by ancient bioclastic mud mixed with ash-sized glass shards and sediment-derived chloritic clasts. (b) Thin plane-parallel beds of facies D. Sparse scoriaceous blocks form overlying wave structures in the stratification (sub-facies D1 of Fig. 4d). The beds are planar, wavy laminated or slightly convolute in sub-facies D2 (Fig. 4d).
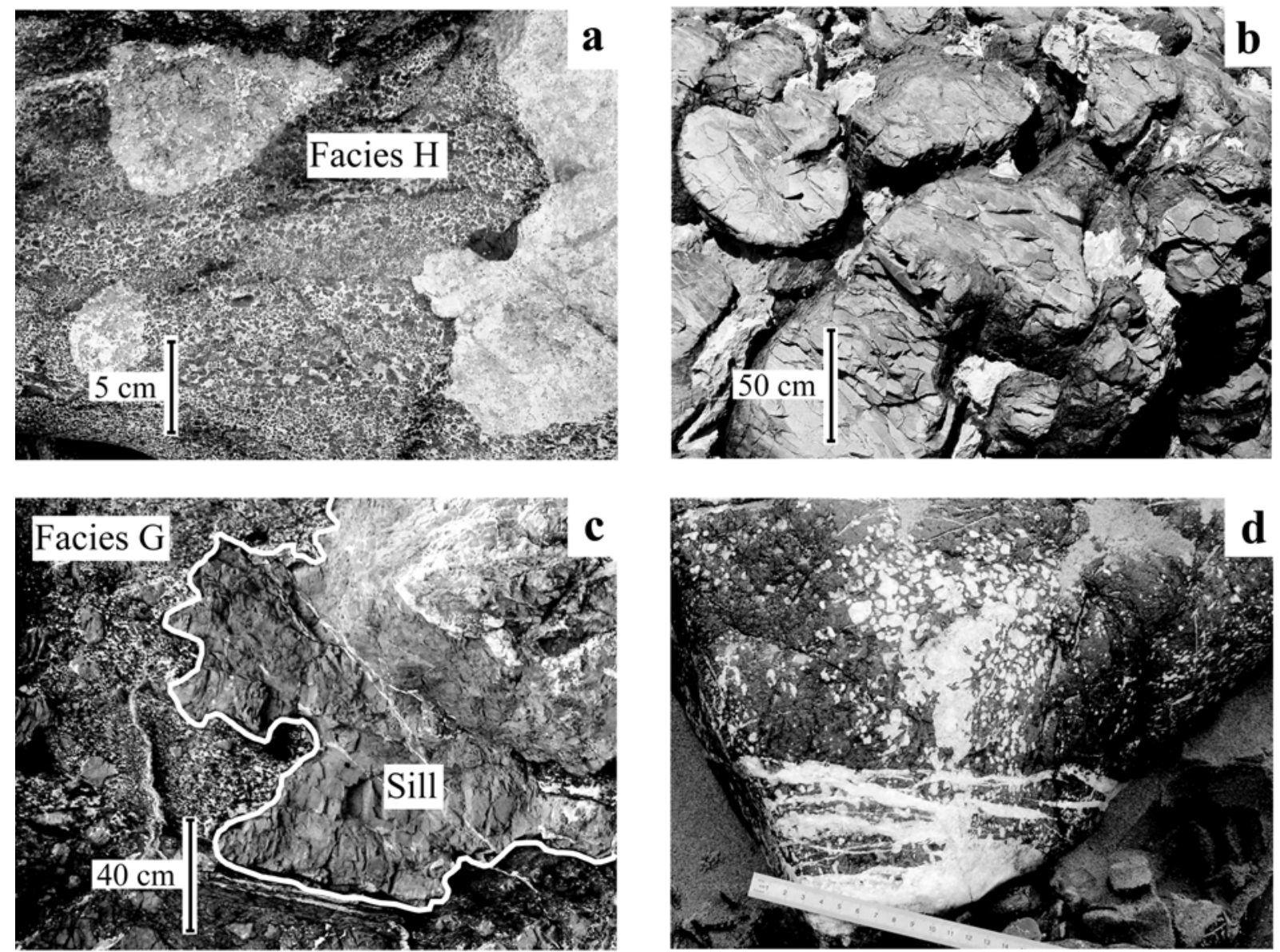

Fig. 9. Photographs of volcanic and peperitic features from the Lostmarc'h Headland (Rosan Formation). (a) Contact between the peperitic graded breccia (facies $\mathrm{H}$ of Fig. 4i) and the overlying L3 limestone (Fig. 3). Limestone is found as enclaves within the breccia. (b) Basaltic pillow lavas with interstitial bioclastic limestone (Fig. 3). (c) Sill intruded into the Gtype monomict breccia (Fig. 3 and 4h). (d) Calcitic plume in a lava block, issued from a thin carbonated level (see text for explanation). 


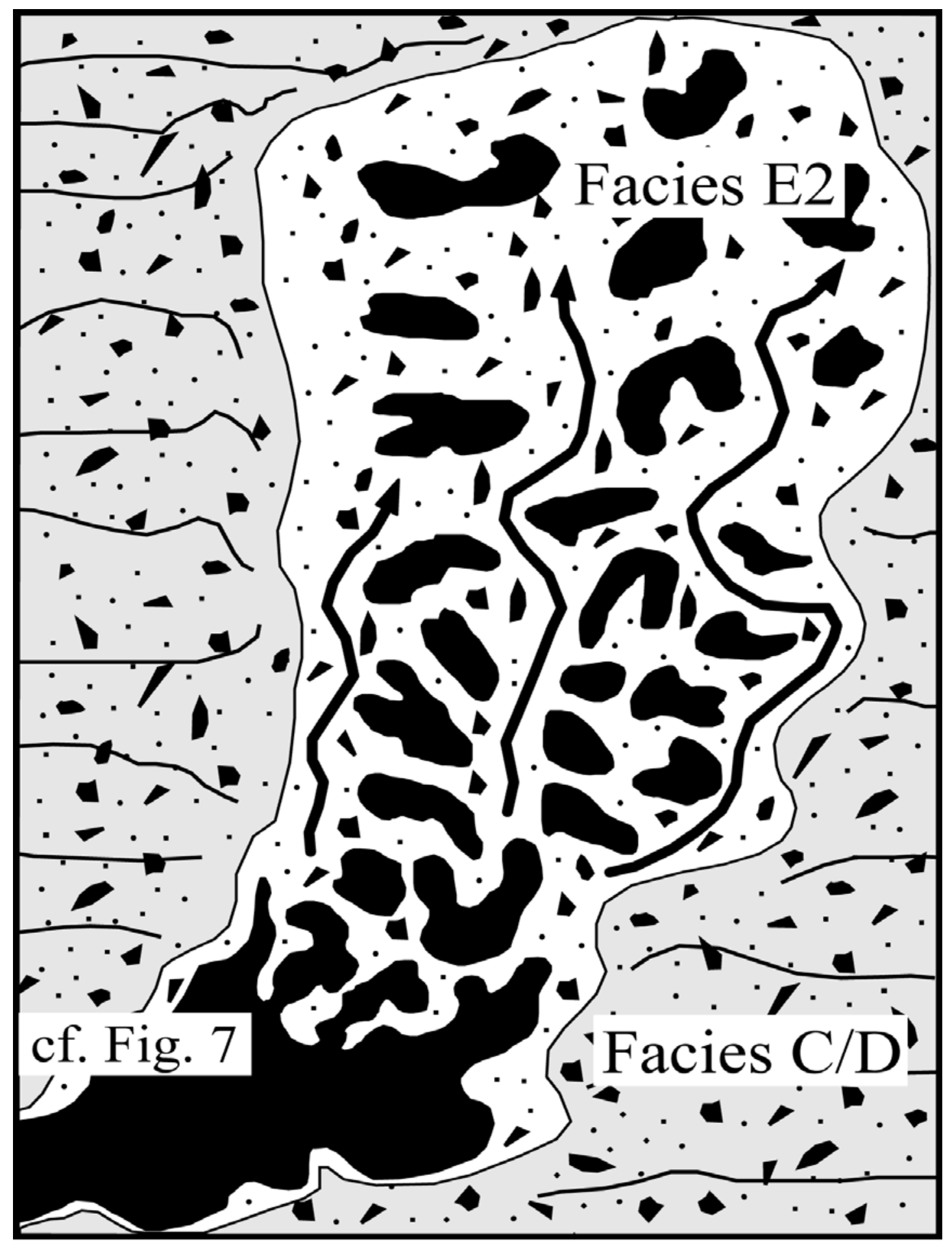

Fig. 10. Model of sill intrusion into unconsolidated wet volcaniclastic deposits of repeated C/D facies type, followed by its progressive disintegration into pillow-like clasts. The nearspherical magmatic clasts of the E2-type non-stratified peperitic breccia from Aber could have been formed through such a mechanism. The smaller peperitic clasts observed in the E1type breccia might also result from a comparable mechanism, but with a higher degree of disintegration, perhaps associated with local phreatomagmatic disruption along the intrusive bodies (not shown). Modified after Martin and Németh (2007). 

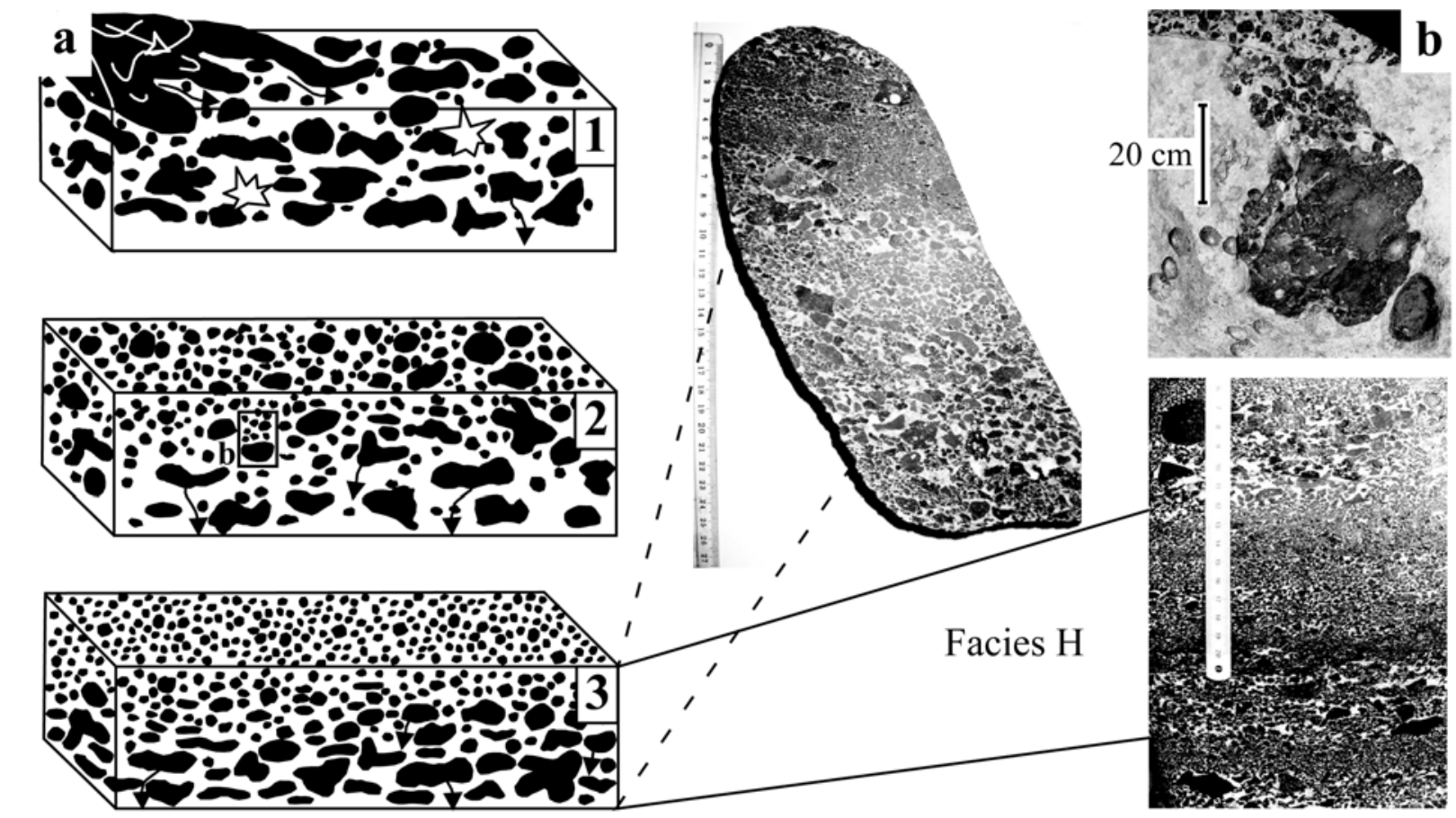

Fig. 11. (a) Model of lava flow disintegration during emplacement into soft sediments. Modified after Brown and Bell (2007). The Lostmarc'h H-type graded peperitic breccia sequences are thought to have resulted from such a process. (b) Lava block isolated within limestone, with a train of small clasts behind. This feature is interpreted as the consequence of the sinking of a large volcanic fluidal fragment into the lime mud after in situ brecciation of the lava flow. 


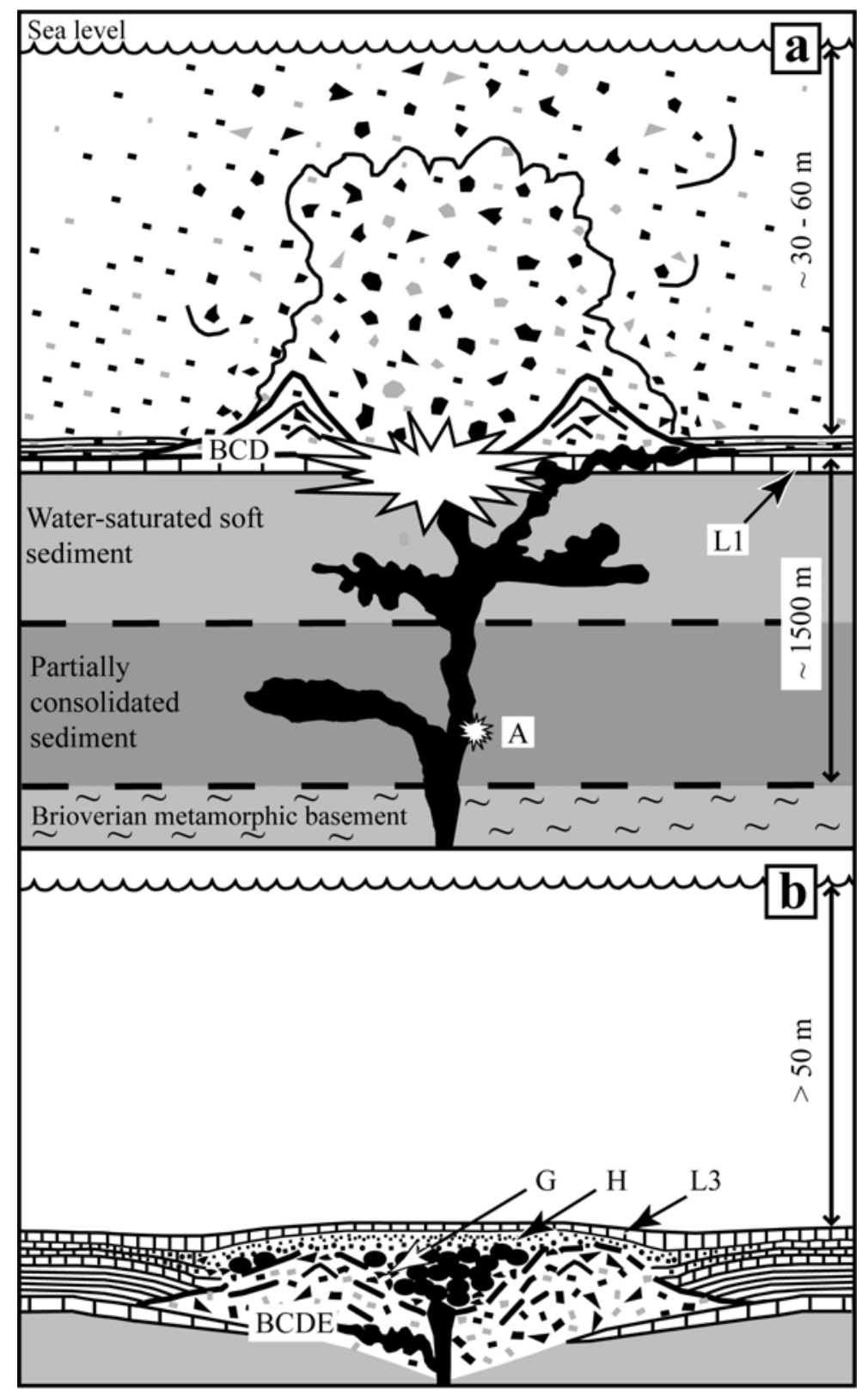

Fig. 12. Schematic representation of the evolution of the volcanic system of Crozon. (a) Eruption, transport and depositional mechanisms thought to have formed the A-type hypabyssal breccia (Kerdreux), the groundlevel volcaniclastic succession (BCD lithofacies association of Aber) and the intrusive peperites (E-type breccias and intrusions from Postolonnec/Aber). Dykes and sills intruded the surrounding soft substrate and the volcaniclastic deposits after they had incorporated sedimentary bits in the course of their progression. The morphology of the peperitic intrusions at different palaeodepths suggests that the substrate was less hydrated and more cemented deep down, but not completely lithified. The volcano(es) had probably the structure of one (or several) subaqueous tuff cone(s). If subaqueous eruption within a soft-sediment environment is unlikely to produce a highly positive constructive volcanic form (Belousov and Belousova, 2001; Martin et al., 2004), the lack of curved contacts and truncated beds and the absence of abrupt changes in dip inclination within the Crozon volcaniclastic succession do not allow proposing a negative form either. (b)

Volcano section just after the end of the activity. Pillow lavas, associated F- (not shown) and G-type breccias and H-type effusive peperitic breccia postdate the phreatomagmatic events. Depths have been estimated from sedimentological and palaeontological/taphonomic observations in the L1, L2, and L3 limestone beds (Fig. 3). 
Table 1. Chemical data (wt $\%$ oxide, ppm element) on whole rock dyke samples.

\begin{tabular}{|c|c|c|c|c|c|}
\hline $\begin{array}{l}\text { Location } \\
\text { Sample } \\
\text { Affinity }\end{array}$ & $\begin{array}{l}\text { Morgat } \\
\text { CNM1 } \\
\text { Tholeiitic }\end{array}$ & $\begin{array}{l}\text { Kerdreux } \\
\text { CNX1 } \\
\text { Tholeiitic }\end{array}$ & $\begin{array}{l}\text { Kerdreux } \\
\text { CNX3 } \\
\text { Alkalic } \\
\end{array}$ & $\begin{array}{l}\text { Kerdra } \\
\text { Ka2 } \\
\text { Tholeiitic }\end{array}$ & $\begin{array}{l}\text { Trégarvan } \\
\text { Ga1 } \\
\text { Transitional }\end{array}$ \\
\hline $\mathrm{SiO}_{2}$ & 46.80 & 50.90 & 48.00 & 50.25 & 49.25 \\
\hline $\mathrm{TiO}_{2}$ & 1.13 & 2.20 & 2.81 & 2.07 & 1.78 \\
\hline $\mathrm{Al}_{2} \mathrm{O}_{3}$ & 14.85 & 13.02 & 14.05 & 13.95 & 14.95 \\
\hline $\mathrm{Fe}_{2} \mathrm{O}_{3}{ }^{\mathrm{t}}$ & 12.55 & 15.60 & 13.30 & 14.80 & 12.75 \\
\hline $\mathrm{MnO}$ & 0.17 & 0.18 & 0.25 & 0.18 & 0.18 \\
\hline $\mathrm{MgO}$ & 7.85 & 3.58 & 5.60 & 4.13 & 5.25 \\
\hline $\mathrm{CaO}$ & 9.70 & 7.92 & 6.65 & 6.25 & 7.80 \\
\hline $\mathrm{Na}_{2} \mathrm{O}$ & 1.88 & 2.82 & 3.88 & 4.75 & 4.48 \\
\hline $\mathrm{K}_{2} \mathrm{O}$ & 0.62 & 0.04 & 0.13 & 0.68 & 0.23 \\
\hline $\mathrm{P}_{2} \mathrm{O}_{5}$ & 0.14 & 0.29 & 0.60 & 0.21 & 0.23 \\
\hline L.O.I. & 3.53 & 2.85 & 4.03 & 2.37 & 2.90 \\
\hline Total & 99.22 & 99.40 & 99.30 & 99.64 & 99.80 \\
\hline $\mathrm{Sr}$ & 247 & 215 & 495 & 242 & 265 \\
\hline $\mathrm{Sc}$ & 25 & 29 & 22 & 34 & 28 \\
\hline V & 192 & 258 & 210 & 302 & 240 \\
\hline $\mathrm{Cr}$ & 328 & 20 & 182 & 60 & 224 \\
\hline Co & 57 & 41 & 45 & 44 & 36 \\
\hline $\mathrm{Ni}$ & 157 & 16 & 124 & 37 & 77 \\
\hline $\mathrm{Y}$ & 20 & 30 & 28 & 31 & 24 \\
\hline $\mathrm{Nb}$ & 7.6 & 13.7 & 29.5 & 14.0 & 15.6 \\
\hline $\mathrm{La}$ & 7.0 & 12.0 & 23.0 & 12.0 & 12.5 \\
\hline $\mathrm{Ce}$ & 15.0 & 27.5 & 51.5 & 25.5 & 26.5 \\
\hline $\mathrm{Nd}$ & 9.0 & 18.0 & 34.0 & 15.8 & 16.0 \\
\hline $\mathrm{Sm}$ & 2.75 & 5.35 & 8.3 & 4.5 & 4.1 \\
\hline $\mathrm{Eu}$ & 0.99 & 1.90 & 2.46 & 1.54 & 1.49 \\
\hline Gd & 2.9 & 6.0 & 7.7 & 5.4 & 5.1 \\
\hline Dy & 3.4 & 5.7 & 5.7 & 5.6 & 4.4 \\
\hline Er & 1.9 & 2.6 & 2.1 & 2.7 & 2.0 \\
\hline $\mathrm{Yb}$ & 1.71 & 2.34 & 1.58 & 2.60 & 1.91 \\
\hline Th & 0.95 & 1.35 & 1.95 & 1.85 & 2.00 \\
\hline
\end{tabular}

ICP-AES analyses (analyst: J. Cotten, Brest). Data for Kerdra and Trégarvan from Juteau et al. (2007). 
Table 2 Description and interpretation of the breccias

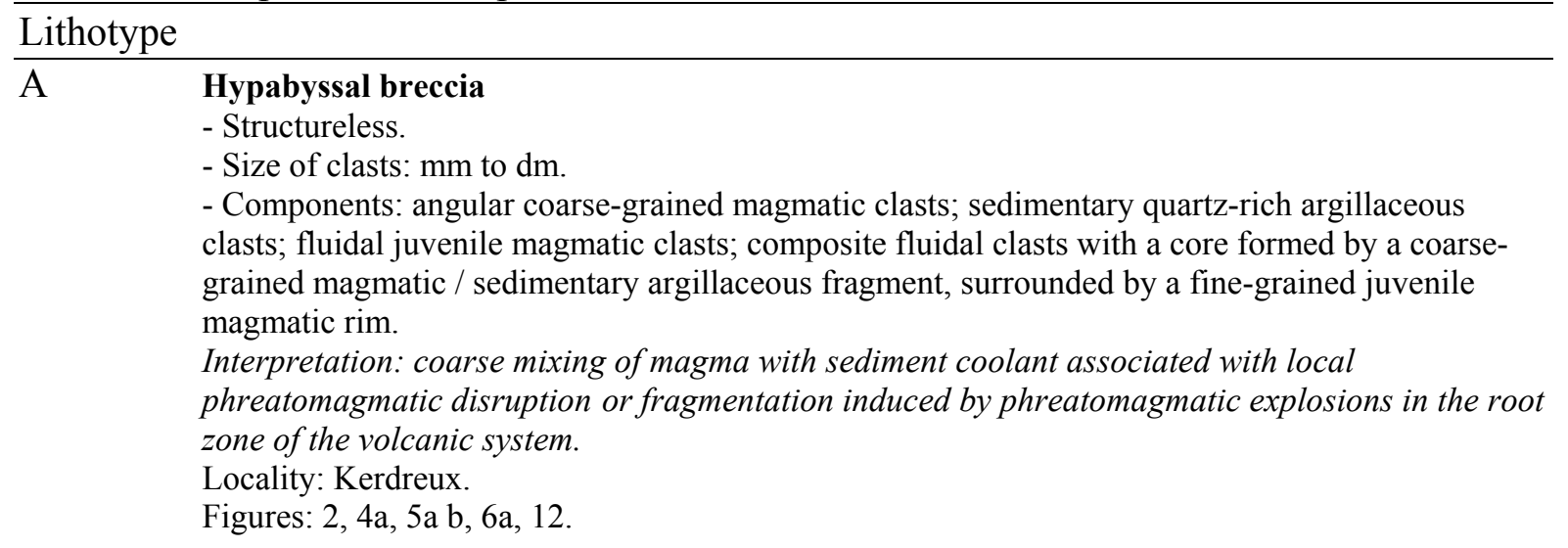

B Crudely stratified volcaniclastic deposits (calcareous matrix)

- Base of the BCD succession.

- Weakly normally graded, poorly sorted 1-2 m-thick beds.

- Size of the clasts: $<5 \mathrm{~cm}$.

- Clasts: abundant fluidal and vesicular sediment-derived chloritic clasts; sparse angular, plagioclase-phyric, slightly vesicular volcanic fragments.

- Matrix: calcareous bioclasts with volcanic shards and chloritic sediment-derived microfragments.

Interpretation: deposits of water-supported gravity mass flows and/or result of high concentration suspension sedimentation derived from subaqueous concentrated tephra jets. Probable incorporation of unconsolidated fossil-rich lime mud into the erupting vent.

Locality: Aber.

Figures: 3, 4b.

Crudely stratified volcaniclastic deposits (silicic matrix)

- Interbedded with facies D.

- Poorly sorted 1-2 m-thick.

- Size of the clasts: $<5 \mathrm{~cm}$.

- Clasts: abundant fluidal and vesicular sediment-derived chloritic clasts; sparse angular, plagioclase-phyric and slightly vesicular volcanic fragments; sparse armored lapilli.

- Silicic bioclastic matrix with volcanic shards and chloritic sediment-derived micro-fragments.

Interpretation: deposits of water-supported gravity mass flows and/or result of high concentration suspension sedimentation derived from subaqueous concentrated tephra jets. Probable incorporation of unconsolidated fossil-rich (secondary silicified) lime mud into the erupting vent. The armored lapilli are inferred to have been formed in subaqueous conditions from a steam envelope that developed above the vent due to magma-water interaction.

Locality: Aber.

Figures: 3, 4c, 8a, 10, 12.

D Thin-bedded volcaniclastic deposits

- Interbedded with facies C.

- Sometimes lenticular, well-sorted thin beds (from a few millimeters to a few centimeters in thickness).

- Abundant fluidal sediment-derived chloritic clasts and sparse angular volcanic clasts in a mixed matrix, composed of ash, chlorite and bioclast-bearing siliceous patches.

- Sub-facies D1: lithic fragments $<1 \mathrm{~cm}$ in length; planar matrix-poor beds.

- Sub-facies D2: lithic fragments $<1 \mathrm{~mm}$ in length; planar, wavy or convolute matrix-rich bedding; elongated volcanic microclasts in a parallel direction with the laminae; mm-sized load structures.

Interpretation: submarine product of dilute, lithic-poor turbulent flows or eruption-fed turbidity currents around the periods of eruptive rest.

Locality: Aber.

Figures: 3, 4d, 6b, 8b, 10, 12. 
- Coarse breccias enclosing fluidal magmatic clasts.

- Matrix: Highly fluidal (sediment-derived) chloritic and magmatic fragments surrounded by siliceous microbioclastic cement. Sparse small angular magmatic fragments.

- Sub-facies E1: weakly graded breccia bearing fluidal magmatic and sediment-derived chloritic clasts, less than $2 \mathrm{~cm}$ in length.

- Sub facies E2: near-spherical magmatic clasts up to $30 \mathrm{~cm}$ in diameter.

Interpretation: Ductile disintegration of sills during their intrusion into soft BCD-type

volcaniclastic breccias.

Locality: Aber.

Figures: 3, 4e f, 6c.

\section{Calcareous conglomerate}

- Upon bioclastic limestone beds, laterally equivalent to pillow lavas.

- Components: plagioclase-phyric volcanic and sediment-derived chloritic rounded pebbles, from millimeter to centimeter in diameter, associated with biogenic debris (crinoids and brachiopods). - Matrix: exclusively formed of biogenic microdebris and recrystallized calcite.

Interpretation: post-eruption remobilization of volcaniclastic debris and sedimentation with bioclasts.

Locality: Aber/Rosan.

Figures: $3,4 \mathrm{~g}$.

\section{Chaotic monomict basaltic breccias}

- Associated with pillow-lavas.

- Structureless.

- Jigsaw-fit angular fragments or lobate clasts.

- The matrix resulted from the crushing of similar material (in local association with bioclasts and/or recrystallised calcite).

Interpretation: fragmentation of the Lostmarc'h pillow lavas, either during their emplacement (autobrecciation) or after flowing (talus accumulation).

Locality: Lostmarc'h.

Figures: 3, 4h, 9c.

\section{Rhythmic fining-up graded peperitic breccia}

- Upon the Lostmarc'h pillow-lavas and beneath a thick bioclastic limestone bed (L3 in Fig. 3). - Well-developed fining-up graded sequences, from a few centimeters to a few decimeters in thickness.

- Clasts: highly fluidal plagioclase-phyric altered volcanic clasts, from one millimeter to two centimeters in length, with rounded, curvilinear or finger-like margins.

- Matrix: calcareous biogenic fragments (crinoids, brachiopods, and bryozoans) cemented with recrystallized calcite.

Interpretation: ductile disintegration of basalt by mingling during flowing within wet, unconsolidated sediment, followed by settling of the largest clasts toward the base of each sequence.

Locality: Lostmarc'h.

Figures: 3, 4i, 6d, 9a, 11, 12. 